\title{
Salt Stress Mitigation via the Foliar Application of Chitosan-Functionalized Selenium and Anatase Titanium Dioxide Nanoparticles in Stevia (Stevia rebaudiana Bertoni)
}

\author{
Morteza Sheikhalipour ${ }^{1}$, Behrooz Esmaielpour ${ }^{1}$ (D), Gholamreza Gohari ${ }^{2, *}$, Maryam Haghighi ${ }^{3}$, Hessam Jafari ${ }^{4}$, \\ Habib Farhadi ${ }^{2}$, Muhittin Kulak ${ }^{5}\left(\right.$ ib and Andrzej Kalisz ${ }^{6, *(1)}$ \\ 1 Department of Horticulture, Faculty of Horticulture, University of Mohagheh Ardabili, \\ Ardabil 13131-56199, Iran; peyman.sh.alipour@gmail.com (M.S.); behsmaiel@yahoo.com (B.E.) \\ 2 Department of Horticulture, Faculty of Horticulture, University of Maragheh, Maragheh 55181-83111, Iran; \\ h.farhadi.14@gmail.com \\ 3 Department of Horticulture, College of Agriculture, Isfahan University of Technology, \\ Isfahan 84156-83111, Iran; mhaghighi@cc.iut.ac.ir \\ 4 Department of Organic Chemistry, Faculty of Chemistry, University of Tabriz, Tabriz 51666-16471, Iran; \\ hessamjafari1996@gmail.com \\ 5 Department of Herbal and Animal Production, Vocational School of Technical Sciences, Igdir University, \\ Igdir 76000, Turkey; muhyttynx@gmail.com \\ 6 Department of Horticulture, Faculty of Biotechnology and Horticulture, University of Agriculture in Krakow, \\ 31-120 Krakow, Poland \\ * Correspondence: gohari.gh@maragheh.ac.ir (G.G.); andrzej.kalisz@urk.edu.pl (A.K.)
}

Citation: Sheikhalipour, M.; Esmaielpour, B.; Gohari, G.; Haghighi, M.; Jafari, H.; Farhadi, H.; Kulak, M.; Kalisz, A. Salt Stress Mitigation via the Foliar Application of Chitosan-Functionalized Selenium and Anatase Titanium Dioxide Nanoparticles in Stevia (Stevia rebaudiana Bertoni). Molecules 2021, 26, 4090. https://doi.org/10.3390/ molecules26134090

Academic Editor: Luísa Durães

Received: 2 May 2021

Accepted: 30 June 2021

Published: 5 July 2021

Publisher's Note: MDPI stays neutral with regard to jurisdictional claims in published maps and institutional affiliations.

Copyright: (c) 2021 by the authors Licensee MDPI, Basel, Switzerland. This article is an open access article distributed under the terms and conditions of the Creative Commons Attribution (CC BY) license (https:/ / creativecommons.org/licenses/by/ $4.0 /)$.

\begin{abstract}
High salt levels are one of the significant and major limiting factors on crop yield and productivity. Out of the available attempts made against high salt levels, engineered nanoparticles (NPs) have been widely employed and considered as effective strategies in this regard. Of these NPs, titanium dioxide nanoparticles $\left(\mathrm{TiO}_{2} \mathrm{NPs}\right)$ and selenium functionalized using chitosan nanoparticles (Cs-Se NPs) were applied for a quite number of plants, but their potential roles for alleviating the adverse effects of salinity on stevia remains unclear. Stevia (Stevia rebaudiana Bertoni) is one of the reputed medicinal plants due to their diterpenoid steviol glycosides (stevioside and rebaudioside A). For this reason, the current study was designed to investigate the potential of $\mathrm{TiO}_{2} \mathrm{NPs}(0,100$ and $\left.200 \mathrm{mg} \mathrm{L}^{-1}\right)$ and Cs-Se NPs $\left(0,10\right.$ and $\left.20 \mathrm{mg} \mathrm{L}^{-1}\right)$ to alleviate salt stress $(0,50$ and $100 \mathrm{mM} \mathrm{NaCl})$ in stevia. The findings of the study revealed that salinity decreased the growth and photosynthetic traits but resulted in substantial cell damage through increasing $\mathrm{H}_{2} \mathrm{O}_{2}$ and MDA content, as well as electrolyte leakage (EL). However, the application of $\mathrm{TiO}_{2} \mathrm{NPs}\left(100 \mathrm{mg} \mathrm{L}^{-1}\right)$ and Cs-Se NPs (20 $\mathrm{mg} \mathrm{L}^{-1}$ ) increased the growth, photosynthetic performance and activity of antioxidant enzymes, and decreased the contents of $\mathrm{H}_{2} \mathrm{O}_{2}, \mathrm{MDA}$ and EL under the saline conditions. In addition to the enhanced growth and physiological performance of the plant, the essential oil content was also increased with the treatments of $\mathrm{TiO}_{2}\left(100 \mathrm{mg} \mathrm{L}^{-1}\right)$ and Cs-Se NPs $\left(20 \mathrm{mg} \mathrm{L}^{-1}\right)$. In addition, the tested NPs treatments increased the concentration of stevioside (in the non-saline condition and under salinity stress) and rebaudioside A (under the salinity conditions) in stevia plants. Overall, the current findings suggest that especially $100 \mathrm{mg} \mathrm{L}^{-1} \mathrm{TiO}_{2} \mathrm{NPs}$ and $20 \mathrm{mg} \mathrm{L}^{-1} \mathrm{Cs}-\mathrm{Se}$ could be considered as promising agents in combating high levels of salinity in the case of stevia.
\end{abstract}

Keywords: abiotic stress; antioxidant enzymes; essential oil; nanotechnology; oxidative stress; steviol glycosides

\section{Introduction}

Salt stress is one of the widely investigated abiotic stress factors because of its clearly reported adverse effects on plant growth and development, as manifested in crop yield loss [1-4]. Regarding osmotic adjustment, ion toxicity and oxidative stress, the negative 
effects of salt stress were reported for a quite number of plant species in recent years [5-8]. These reports suggest that most of the agronomically important crop species are not compatible with high salt levels, as uttered in a review by Parihar et al. [4]. Furthermore, the Food and Agriculture Organization (FAO) reports stated that salinity is a serious threat to over $6 \%$ of the world's land [4] and the relevant reports anticipate that salinity will severely affect more than $50 \%$ of arable land by 2050 [9]. For this reason, the use of new methods and strategies to decrease the negative effects of salinity has gained great importance. Of the recent attempts undertaken, nanoscale materials were employed as a nanotechnological approach and accordingly exhibited protective roles for quite a number of crop plants, suggesting the better tolerance of plants against the harsh conditions [10,11].

Nanotechnology is the study and application of nanoscale particles with specific qualities and small diameters (1-100 nm); they are widely applied in various agriculture aspects, such as plant nutrition, plant protection and nanopesticides [12]. The relevant studies regarding functionalization, modification or newly conjugated structures of nanoparticles are some of the emerging and hot topics nowadays [10]. Out of the available nanomaterials, cerium dioxide $\left(\mathrm{nCeO}_{2}\right)$ [13-16], magnetite $\left(\mathrm{nFe}_{3} \mathrm{O}_{4}\right)$ [17-19], zinc oxide (nZnO) [20], silicon dioxide $\left(\mathrm{nSiO}_{2}\right)$ [21], copper oxide $(\mathrm{nCuO})$ [22], aluminum oxide $\left(\mathrm{nAl}_{2} \mathrm{O}_{3}\right)$ [23] and carbon nanotubes [24] showed protective roles in plants under stress conditions. In the case of medicinal and aromatic plant species, the application of nanoparticles is one of the novel and wise strategies used to increase growth, yield and especially secondary metabolites in plants under salt stress [25]. Moreover, selenium functionalized by a chitosan nanocomposite (Cs-Se NPs) and titanium dioxide nanoparticles ( $\mathrm{TiO}_{2} \mathrm{NPs}$ ) are some of the proven substantial molecules that are used to enhance the abiotic tolerance range of the crop via the activation of defense mechanisms [26,27]. Considering the relevant stress indicators, treatments of $\mathrm{TiO}_{2}$ NPs and Cs-Se NPs decreased MDA and $\mathrm{H}_{2} \mathrm{O}_{2}$ content and increased agronomic parameters, photosynthetic pigments content, chlorophyll fluorescence, soluble sugars, proline content and antioxidant enzymes activity in some plant species under salinity stress $[25,27,28]$. In addition to the enhanced crop productivity under salinity stress, total phenolic compounds and essential oil yield were also increased with $\mathrm{TiO}_{2} \mathrm{NPs}$ and Cs-Se NPs treatments $[25,27,29]$. However, high $\mathrm{TiO}_{2} \mathrm{NP}$ concentration decreased the growth parameters, photosynthetic pigments and antioxidant activity and increased MDA and $\mathrm{H}_{2} \mathrm{O}_{2}$ in the plant $[25,28]$.

Stevia (Stevia rebaudiana Bertoni) belongs to the Asteraceae family and is a reputed medicinal plant, possessing diterpenoid steviol glycosides (i.a., stevioside and rebaudioside A), which are 300 times sweeter than sucrose. For this reason, stevia is known as sweet leaf or sugar leaf. Since the human body does not metabolize the glycosides of stevia, stevia contains zero calories. This property of stevia leads the plant to be assessed as a natural sweetener to control diabetes. In order to reveal the changes of these metabolites and other relevant biochemical responses of stevia against salt stress, a wide array of welldocumented studies were undertaken [30-35]. However, to our best knowledge, no studies have hitherto investigated the effects of $\mathrm{TiO}_{2}$ NPs and Cs-Se NPs on stevia grown under salt stress. Corresponding to the enhancing and stimulating roles of elements and their application as nanoparticles at non-toxic concentrations, we hypothesized that the relevant nanoparticles will improve the antioxidant status, steviol glycosides and other physiological parameters of stevia; furthermore, these improvements will be manifested in the growth and development of stevia. Both nanoparticle types were previously tested $[25,27]$ and produced promising results related to plant growth, the alleviation of salt stress and an increase in plant chemical constituents desired by humans. As deduced from the findings from the studies by Gohari et al. [25] and Sheikhalipour et al. [27], three concentrations of $\mathrm{TiO}_{2}$ NPs $\left(0,100\right.$ and $\left.200 \mathrm{mg} \mathrm{L}^{-1}\right)$ and Cs-Se NPs (0, 10 and $\left.20 \mathrm{mg} \mathrm{L}^{-1}\right)$ were assayed for the current study. Therefore, our research group set out to test the effects of these molecules on a new valuable plant species, namely, stevia, as part of a series of studies in this research area. 


\section{Results}

\subsection{Effect of Cs-Se NPs and $\mathrm{TiO}_{2}$ NPs on Plant Growth Parameters}

Salinity significantly decreased the plant growth parameters, where higher salt levels decreased the shoot height by $40.83 \%$, root height by $37.45 \%$, shoot fresh weight by $62.67 \%$, root fresh weight by $51.26 \%$, shoot dry weight by $64.11 \%$ and root dry weight by $50.68 \%$ as compared with the non-saline condition (Table 1). However, the application of $\mathrm{TiO}_{2}$ NPs and Cs-Se NPs significantly increased the plant growth parameters under the saline conditions. The current findings revealed that the Cs-Se NPs $\left(20 \mathrm{mg} \mathrm{L}^{-1}\right)$ treatment positively affected the shoot height $(17.80 \%$ and $18.94 \%)$, root height $(9.82 \%$ and $13.32 \%)$, shoot fresh weight $(16.26 \%$ and $16.43 \%)$, root fresh weight $(7.16 \%$ and $11.52 \%)$, shoot dry weight $(17.87 \%$ and $23.70 \%)$ and root dry weight $(7.07 \%$ and $13.47 \%)$ under the $50 \mathrm{mM}$ and $100 \mathrm{mM}$ salt levels, respectively, in comparison with the non-NP-treated plants.

Out of the applied $\mathrm{TiO}_{2}$ NP levels, $\mathrm{TiO}_{2}$ NPs $\left(100 \mathrm{mg} \mathrm{L}^{-1}\right)$ significantly improved the shoot height $(14.94 \%$ and $17.27 \%)$, root height $(8.92 \%$ and $11.30 \%)$, shoot fresh weight (11.19\% and $16.74 \%)$, root fresh weight (5.92\% and $10.66 \%)$, shoot dry weight $(12.74 \%$ and $23.94 \%)$ and root dry weight (6.17\% and $11.07 \%)$ under the $50 \mathrm{mM}$ and $100 \mathrm{mM}$ salt levels, respectively, in comparison with the non-NP-treated plants (Table 1).

2.2. Effect of $\mathrm{Cs}-\mathrm{Se} N \mathrm{NP}$ and $\mathrm{TiO}_{2} \mathrm{NPs}$ on Photosynthetic Pigments, Net Photosynthetic Rate (Pn) and Maximum Quantum Efficiency of Photosystem II (Fv/Fm)

Salinity significantly decreased chlorophyll $a$ and $b$, total chlorophyll, carotenoid concentrations, Pn and Fv/Fm (Table 1). However, the $\mathrm{TiO}_{2}$ NPs and Cs-Se NPs exhibited positive effects on the photosynthetic pigments, Pn and Fv/Fm under salinity. The current findings showed that a $100 \mathrm{mM}$ salinity concentration decreased chlorophyll $a$ by $46.63 \%$, chlorophyll $b$ by $23.46 \%$, total chlorophyll by $43.96 \%$, carotenoid by $21.99 \%$, Pn by $22.42 \%$ and Fv / Fm by $15.48 \%$ in comparison with the non-saline condition. Cs-Se NPs $\left(20 \mathrm{mg} \mathrm{L}^{-1}\right)$ increased content of chlorophyll $a(12.18 \%$ and $15.38 \%)$, chlorophyll $b(2.73 \%$ and $7.70 \%)$, total chlorophyll (11.07\% and 14.04\%), carotenoid (6.72\% and $8.71 \%)$, Pn (5.82\% and 7.96\%) and $\mathrm{Fv} / \mathrm{Fm}(3.38 \%$ and $10.27 \%)$ in comparison with non-treated plants under the $50 \mathrm{mM}$ and $100 \mathrm{mM}$ salt levels, respectively. Furthermore, $\mathrm{TiO}_{2} \mathrm{NPs}\left(100 \mathrm{mg} \mathrm{L}^{-1}\right)$ significantly enhanced the concentration of chlorophyll $a(11.04 \%$ and $10.73 \%)$, chlorophyll $b(3.92 \%$ and $8.11 \%)$, total chlorophyll (10.21\% and $10.22 \%)$, carotenoid $(7.05 \%$ and $7.05 \%)$, Pn $(4.21 \%$ and $6.64 \%)$ and $\mathrm{Fv} / \mathrm{Fm}(1.46 \%$ and $8.64 \%$ ) parameters in comparison with non-treated plants under the $50 \mathrm{mM}$ and $100 \mathrm{mM}$ salt levels, respectively (Table 1). 


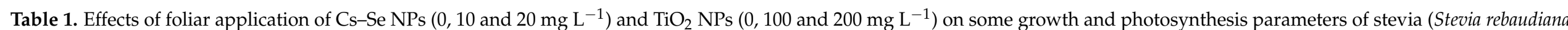
Bertoni) under different salt stress $(0,50$ and $100 \mathrm{mM} \mathrm{NaCl})$ treatments.

\begin{tabular}{|c|c|c|c|c|c|c|c|c|c|c|c|c|c|}
\hline $\mathrm{NaCl}(\mathrm{mM})$ & Treatments & $\begin{array}{c}\text { Shoot Height } \\
(\mathrm{cm})\end{array}$ & $\begin{array}{l}\text { Root Height } \\
\text { (m) }\end{array}$ & $\begin{array}{c}\text { Shoot FW } \\
\text { (g) }\end{array}$ & $\begin{array}{c}\text { Shoot DW } \\
(\mathrm{g})\end{array}$ & $\underset{(\mathrm{g})}{\operatorname{Root~FW}}$ & $\underset{(\mathrm{g})}{\mathrm{Root} \text { DW }}$ & $\underset{\left(\mathrm{mg} \mathrm{g}^{-1} \mathrm{CHW}\right)}{\mathrm{Cl} a}$ & $\underset{\left(\mathrm{mg} \mathrm{g}^{-1} \mathrm{FW}\right)}{\mathrm{Cl} b}$ & $\begin{array}{c}\text { Total Chl } \\
\left(\mathrm{mg} \mathrm{g}^{-1} \mathrm{FW}\right)\end{array}$ & $\begin{array}{c}\text { Carotenoids } \\
\text { (mg g textsuperscript-1 } \\
\text { FW) }\end{array}$ & $\mathrm{Fv} / \mathrm{Fm}$ & $\underset{\left(\mu \mathrm{mol} \mathrm{m}^{-2} \mathrm{~s}^{-1}\right)}{\mathrm{Pn}}$ \\
\hline \multirow{5}{*}{0} & No Treatment & $46.72 \pm 1.74 \mathrm{ab}$ & $17.06 \pm 0.40 \mathrm{a}$ & $107.99 \pm 4.50 \mathrm{a}$ & $20.09 \pm 0.67 \mathrm{a}$ & $30.08 \pm 0.17 \mathrm{a}$ & $5.86 \pm 0.04 \mathrm{a}$ & $6.39 \pm 0.18^{\mathrm{a}}$ & $0.814 \pm 0.012 \mathrm{a}$ & $7.21 \pm 0.18^{\mathrm{a}}$ & $5.91 \pm 0.12 \mathrm{a}$ & $0.775 \pm 0.010^{b}$ & $9.23 \pm 0.04^{c}$ \\
\hline & $\mathrm{TiO}_{2} \mathrm{NPs}_{100 \mathrm{mg} \mathrm{L}^{-1}}$ & $46.93 \pm 2.64 \mathrm{ab}$ & $17.56 \pm 0.21 \mathrm{a}$ & $107.88 \pm 6.12 \mathrm{a}$ & $20.11 \pm 0.94 \mathrm{a}$ & $30.15 \pm 0.23 \mathrm{a}$ & $5.93 \pm 0.03 \mathrm{a}$ & $6.50 \pm 0.21^{a}$ & $0.835 \pm 0.011 \mathrm{a}$ & $7.33 \pm 0.22 \mathrm{a}$ & $5.93 \pm 0.05 \mathrm{a}$ & $0.778 \pm 0.006^{b}$ & $9.38 \pm 0.01 \mathrm{ab}$ \\
\hline & $\mathrm{TiO}_{2} \mathrm{NPs}^{2} 200 \mathrm{mg} \mathrm{L}^{-1}$ & $48.11 \pm 0.74^{\mathrm{a}}$ & $17.23 \pm 0.45 \mathrm{a}$ & $107.75 \pm 6.74 \mathrm{a}$ & $20.12 \pm 1.11^{\mathrm{a}}$ & $30.16 \pm 0.30^{a}$ & $5.92 \pm 0.06 \mathrm{a}$ & $6.44 \pm 0.18 \mathrm{a}$ & $0.819 \pm 0.006 \mathrm{a}$ & $7.26 \pm 0.18 \mathrm{a}$ & $5.89 \pm 0.13 \mathrm{a}$ & $0.772 \pm 0.007 \mathrm{~b}$ & $9.32 \pm 0.01 \mathrm{bc}$ \\
\hline & Cs-Se NPs $10 \mathrm{mg} \mathrm{L}^{-1}$ & $46.80 \pm 1.72 \mathrm{ab}$ & $17.55 \pm 0.32 \mathrm{a}$ & $107.69 \pm 3.69$ a & $20.15 \pm 0.91 \mathrm{a}$ & $29.92 \pm 1.57 \mathrm{a}$ & $5.89 \pm 0.28 \mathrm{a}$ & $6.48 \pm 0.29 \mathrm{a}$ & $0.819 \pm 0.003 \mathrm{a}$ & $7.29 \pm 0.29 \mathrm{a}$ & $5.90 \pm 0.09 \mathrm{a}$ & $0.776 \pm 0.003 \mathrm{~b}$ & $9.39 \pm 0.06 \mathrm{ab}$ \\
\hline & Cs-Se NPs $20 \mathrm{mg} \mathrm{L}^{-1}$ & $47.81 \pm 1.49 \mathrm{a}$ & $17.65 \pm 0.23 \mathrm{a}$ & $108.37 \pm 1.82^{\mathrm{a}}$ & $20.30 \pm 0.45 \mathrm{a}$ & $30.97 \pm 0.41 \mathrm{a}$ & $6.12 \pm 0.10^{\mathrm{a}}$ & $6.59 \pm 0.14^{a}$ & $0.836 \pm 0.012^{\mathrm{a}}$ & $7.43 \pm 0.13 \mathrm{a}$ & $5.97 \pm 0.09 \mathrm{a}$ & $0.789 \pm 0.004 \mathrm{a}$ & $9.48 \pm 0.02 \mathrm{a}$ \\
\hline \multirow{5}{*}{50} & No Treatment & $37.67 \pm 1.57 \mathrm{e}$ & $13.67 \pm 0.23^{\mathrm{c}}$ & $74.87 \pm 3.44 \mathrm{~d}$ & $14.38 \pm 0.41^{\mathrm{c}}$ & $24.60 \pm 0.41^{\mathrm{c}}$ & $4.86 \pm 0.08^{\mathrm{c}}$ & $4.83 \pm 0.09 \mathrm{e}$ & $0.710 \pm 0.00 \mathrm{~d}^{\mathrm{d}}$ & $5.54 \pm 0.08 \mathrm{~d}$ & $5.27 \pm 0.05 \mathrm{~d}$ & $0.741 \pm 0.000 \mathrm{e}$ & $8.41 \pm 0.03 \mathrm{~g}$ \\
\hline & $\mathrm{TiO}_{2} \mathrm{NPs}_{100 \mathrm{mg} \mathrm{L}^{-1}}$ & $44.29 \pm 0.84 \mathrm{bcd}$ & $15.01 \pm 0.15^{\mathrm{b}}$ & $84.31 \pm 2.49 \mathrm{bc}$ & $16.48 \pm 0.26^{b}$ & $26.15 \pm 0.21 \mathrm{bc}$ & $5.18 \pm 0.03 \mathrm{bc}$ & $5.43 \pm 0.08 \mathrm{bc}$ & $0.739 \pm 0.008 \mathrm{~b}$ & $6.17 \pm 0.09 \mathrm{~b}$ & $5.67 \pm 0.07 \mathrm{~b}$ & $0.752 \pm 0.001 \mathrm{~d}$ & $8.78 \pm 0.03 \mathrm{e}^{\mathrm{e}}$ \\
\hline & $\mathrm{TiO}_{2} \mathrm{NPs}_{200 \mathrm{mg} \mathrm{L}^{-1}}$ & $41.60 \pm 1.94 \mathrm{~d}$ & $14.13 \pm 0.25^{c}$ & $79.11 \pm 0.77 \mathrm{~cd}$ & $14.43 \pm 1.00^{\mathrm{C}}$ & $25.49 \pm 1.42 \mathrm{bc}$ & $5.06 \pm 0.29 \mathrm{bc}$ & $5.08 \pm 0.11 \mathrm{de}$ & $0.732 \pm 0.010^{b c}$ & $5.81 \pm 0.12^{\mathrm{C}}$ & $5.34 \pm 0.05^{\mathrm{cd}}$ & $0.754 \pm 0.002 \mathrm{~d}$ & $8.58 \pm 0.06^{\mathrm{f}}$ \\
\hline & Cs-Se NPs $10 \mathrm{mg} \mathrm{L}^{-1}$ & $42.66 \pm 1.56^{\mathrm{cd}}$ & $14.12 \pm 0.48^{\mathrm{C}}$ & $81.60 \pm 1.83^{\mathrm{cd}}$ & $16.04 \pm 0.50 \mathrm{bc}$ & $25.16 \pm 1.06^{b c}$ & $4.97 \pm 0.24 \mathrm{bc}$ & $5.19 \pm 0.11 \mathrm{~cd}$ & $0.715 \pm 0.004 \mathrm{~cd}$ & $5.90 \pm 0.11^{\mathrm{c}}$ & $5.44 \pm 0.08^{c}$ & $0.758 \pm 0.000 \mathrm{~cd}$ & $8.62 \pm 0.03^{\mathrm{F}}$ \\
\hline & Cs-Se NPs $20 \mathrm{mg} \mathrm{L}^{-1}$ & $45.83 \pm 1.17 \mathrm{abc}$ & $15.16 \pm 0.10^{b}$ & $89.41 \pm 1.66^{\mathrm{b}}$ & $17.51 \pm 0.16^{\mathrm{b}}$ & $26.50 \pm 0.73 \mathrm{~b}$ & $5.23 \pm 0.14 \mathrm{~b}$ & $5.50 \pm 0.19 \mathrm{~b}$ & $0.730 \pm 0.001$ bcd & $6.23 \pm 0.19^{\mathrm{b}}$ & $5.65 \pm 0.11 \mathrm{~b}$ & $0.767 \pm 0.004 \mathrm{bc}$ & $8.93 \pm 0.04 \mathrm{~d}$ \\
\hline \multirow{4}{*}{100} & $\mathrm{TiO}_{2} \mathrm{NPs}_{100 \mathrm{mg} \mathrm{L}^{-1}}$ & $\begin{array}{l}27.64 \pm 1.70 \mathrm{fg} \\
33.41 \pm 0.14 \mathrm{fg}\end{array}$ & $\begin{array}{l}1.06 \pm 0.19 \mathrm{de} \\
12.03 \pm 0.14 \mathrm{de}\end{array}$ & $\begin{array}{l}48.0 .41 \pm 0.86^{\circ} \\
48.42 \pm 1.10^{\circ}\end{array}$ & $9.48 \pm 0.40 \mathrm{~d}$ & $\begin{array}{l}11.60 \pm 0.48 \mathrm{~d} \\
16.41 \pm 0.69 \mathrm{~d}\end{array}$ & $\begin{array}{l}2.89 \pm 0.04 \mathrm{~d}^{2} \\
3.25 \pm 0.14 \mathrm{~d}^{2}\end{array}$ & $\begin{array}{l}3.41 \pm 0.08 \mathrm{fr} \\
3.82 \pm 0.02 \mathrm{fg}\end{array}$ & $\begin{array}{l}0.623 \pm 0.0006 \mathrm{x}^{2} \\
0.678 \pm 0.001\end{array}$ & $\begin{array}{l}4.04 \pm 0.070 \text { of } \\
4.50 \pm 0.02 \text { ef }\end{array}$ & $\begin{array}{l}4.61 \pm 0.026 \\
4.96 \pm 0.03 \\
\mathrm{e}\end{array}$ & $\begin{array}{l}0.053 \pm \pm 0.004{ }^{2} \\
0.717 \pm 0.055\end{array}$ & $\begin{array}{l}.16 \pm 0.044^{\mathrm{i}} \\
7.67 \pm 0.0 \mathrm{i}^{\mathrm{s}}\end{array}$ \\
\hline & 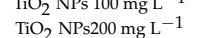 & $\begin{array}{l}33.41 \pm 0.14 \mathrm{~s} \\
30.45 \pm 0.88 \mathrm{gh}\end{array}$ & $\begin{array}{l}12.03 \pm 0.14 \\
11.68 \pm 0.05 \\
\mathrm{e}\end{array}$ & $\begin{array}{l}\text { b } 4.42 \pm 1.10 \text { ef } \\
43.50 \pm 0.57 \text { ef }\end{array}$ & $\begin{array}{l}9.48 \pm 0.40^{\circ} \\
8.76 \pm 0.29 \mathrm{de}\end{array}$ & $\begin{array}{l}11.41 \pm 0.69 \mathrm{e}^{\mathrm{e}} \\
15.75 \pm 0.50 \mathrm{e}\end{array}$ & $\begin{array}{l}3.25 \pm 0.14 \\
3.13 \pm 0.11 \text { de }\end{array}$ & $\begin{array}{l}3.82 \pm 0.022 \mathrm{~g} \\
3.62 \pm 0.01 \mathrm{gh}\end{array}$ & $0.643 \pm 0.0014^{\mathrm{f}}$ & $\begin{array}{l}4.50 \pm 0.02 \\
4.27 \pm 0.02 \mathrm{fg}\end{array}$ & $\begin{array}{l}4.96 \pm 0.003 \mathrm{fg} \\
4.76 \pm 0.03 \mathrm{fg}\end{array}$ & $\begin{array}{l}0.117 \pm 0.0050 \\
0.686 \pm 0.005 \\
\mathrm{~h}\end{array}$ & $\begin{array}{l}\quad .67 \pm 0.04 \mathrm{k} \\
7.42 \pm 0.03 \mathrm{k}\end{array}$ \\
\hline & Cs-Se NPs $10 \mathrm{mg} \mathrm{L}^{-1}$ & $30.68 \pm 0.60$ gh & $12.19 \pm 0.09 \mathrm{de}$ & $42.80 \pm 0.42$ ef & $8.73 \pm 0.52 \mathrm{de}$ & $15.92 \pm 0.20 \mathrm{de}$ & $3.19 \pm 0.04$ de & $3.75 \pm 0.03 \mathrm{~g}$ & $0.668 \pm 0.013 \mathrm{e}$ & $4.42 \pm 0.04 \mathrm{f}$ & $4.79 \pm 0.03^{f}$ & $0.665 \pm 0.004{ }^{\mathrm{i}}$ & $7.53 \pm 0.05 \mathrm{j}$ \\
\hline & Cs-Se NPs $20 \mathrm{mg} \mathrm{L}^{-1}$ & $34.10 \pm 0.14 \mathrm{f}$ & $12.31 \pm 0.08 \mathrm{~d}$ & $48.24 \pm 0.86 \mathrm{e}$ & $9.45 \pm 0.74 \mathrm{~d}$ & $16.57 \pm 0.61 \mathrm{~d}$ & $3.34 \pm 0.10 \mathrm{~d}$ & $4.03 \pm 0.05 \mathrm{f}$ & $0.675 \pm 0.013 \mathrm{e}$ & $4.70 \pm 0.04 \mathrm{e}$ & $\begin{array}{l}4.19 \pm 0.03 \mathrm{e} \\
5.05 \pm 0.03 \mathrm{e}\end{array}$ & $0.730 \pm 0.006 \mathrm{f}$ & $7.78 \pm 0.05^{\mathrm{h}}$ \\
\hline
\end{tabular}

Data are the average of 3 repetitions \pm standard error. Different letters in a column indicate significantly different values according to Duncan's post hoc analysis at $p<0.05$. 


\subsection{Effect of $\mathrm{Cs}-\mathrm{Se} \mathrm{NPs}$ and $\mathrm{TiO}_{2} \mathrm{NPs}$ on Proline Content and $\mathrm{RWC}$}

Salinity significantly increased the proline content and decreased the relative water content (RWC) (Figure 1). The findings of the current study revealed that severe salinity increased the proline content by $41.51 \%$ and decreased the RWC by $39.94 \%$ in comparison with the non-saline condition, whilst treatments of $\mathrm{TiO}_{2} \mathrm{NPs}$ and Cs-Se NPs resulted in higher levels of proline content relative to the 50 and $100 \mathrm{mM} \mathrm{NaCl}$ stress alone. Moreover, $\mathrm{TiO}_{2} \mathrm{NPs}$ and Cs-Se NPs increased the RWC in plants under salinity stress. Our results showed that the treatment with Cs-Se NPs $\left(20 \mathrm{mg} \mathrm{L}^{-1}\right)$ significantly increased the proline content $(5.23 \%$ and $9.35 \%)$ and RWC $(11.73 \%$ and $12.83 \%)$ in comparison with non-treated plants under the 50 and $100 \mathrm{mM}$ salt levels, respectively. Furthermore, $\mathrm{TiO}_{2}$ NPs (100 mg L $\left.{ }^{-1}\right)$ significantly increased the proline content $(7.27 \%$ and $8.40 \%)$ and RWC $(10.60 \%$ and $10.33 \%)$ as compared with the non-treated plants under 50 and $100 \mathrm{mM}$ salt levels, respectively (Figure 1A,B).

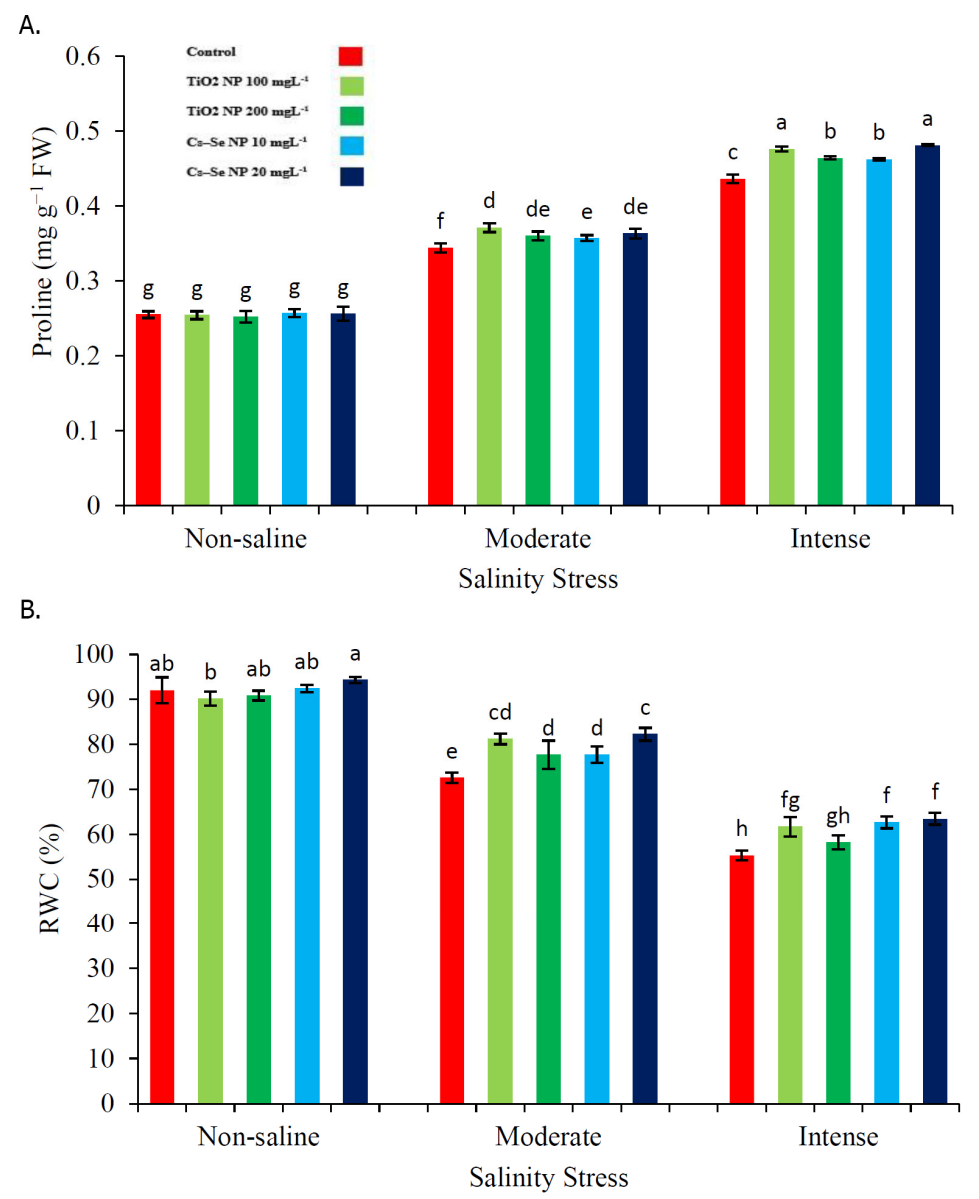

Figure 1. Effect of different concentrations of Cs-Se NPs and $\mathrm{TiO}_{2} \mathrm{NPs}$ on the proline content (A) and RWC (B) of stevia (Stevia rebaudiana Bertoni) leaf under salinity stress. Data are the average of 3 repetitions \pm standard error. Different letters indicate significantly different values according to Duncan's post hoc analysis at $p<0.05$.

\subsection{Effect of Cs-Se NPs and $\mathrm{TiO}_{2} \mathrm{NPs}$ on Leaf Content of $\mathrm{MDA}$ and $\mathrm{H}_{2} \mathrm{O}_{2}$, as Well as Electrolyte Leakage}

As expected, salinity caused substantial increases in leaf MDA, $\mathrm{H}_{2} \mathrm{O}_{2}$ and electrolyte leakage. The highest leaf MDA $\left(5.41 \mathrm{nM} \mathrm{mg}^{-1} \mathrm{FW}\right), \mathrm{H}_{2} \mathrm{O}_{2}$ content $\left(96.40 \mathrm{nM} \mathrm{mg}^{-1} \mathrm{FW}\right)$ and electrolyte leakage $(88.30 \%$ ) were observed under the severe salinity condition (Figure 2 ). For the case regarding the enhanced agronomic performance and photosynthetic pigment concentration, both treatments of $\mathrm{Cs}-\mathrm{Se} \mathrm{NPs}$ and $\mathrm{TiO}_{2} \mathrm{NPs}$ substantially affected the leaf contents of MDA and $\mathrm{H}_{2} \mathrm{O}_{2}$, as well as electrolyte leakage. Corresponding to the treatments, 
Cs-Se NPs (20 mg L $\left.{ }^{-1}\right)$ significantly decreased the content of MDA (38.52\% and 22.18\%) and $\mathrm{H}_{2} \mathrm{O}_{2}(9.34 \%$ and $10.38 \%)$, as well as electrolyte leakage (22.06\% and $\left.12.45 \%\right)$, in relation to the non-treated plants grown under the $50 \mathrm{mM}$ and $100 \mathrm{mM}$ salinity levels, respectively. Moreover, the $\mathrm{TiO}_{2} \mathrm{NPs}\left(100 \mathrm{mg} \mathrm{L}^{-1}\right)$ treatment significantly decreased the content of MDA (34.69\% and $18.11 \%)$ and $\mathrm{H}_{2} \mathrm{O}_{2}(11.16 \%$ and $9.11 \%)$, as well as electrolyte leakage $(14.25 \%$ and $9.66 \%)$, as compared with the non-treated plants under $50 \mathrm{mM}$ and $100 \mathrm{mM}$ levels of salinity (Figure 2A-C).
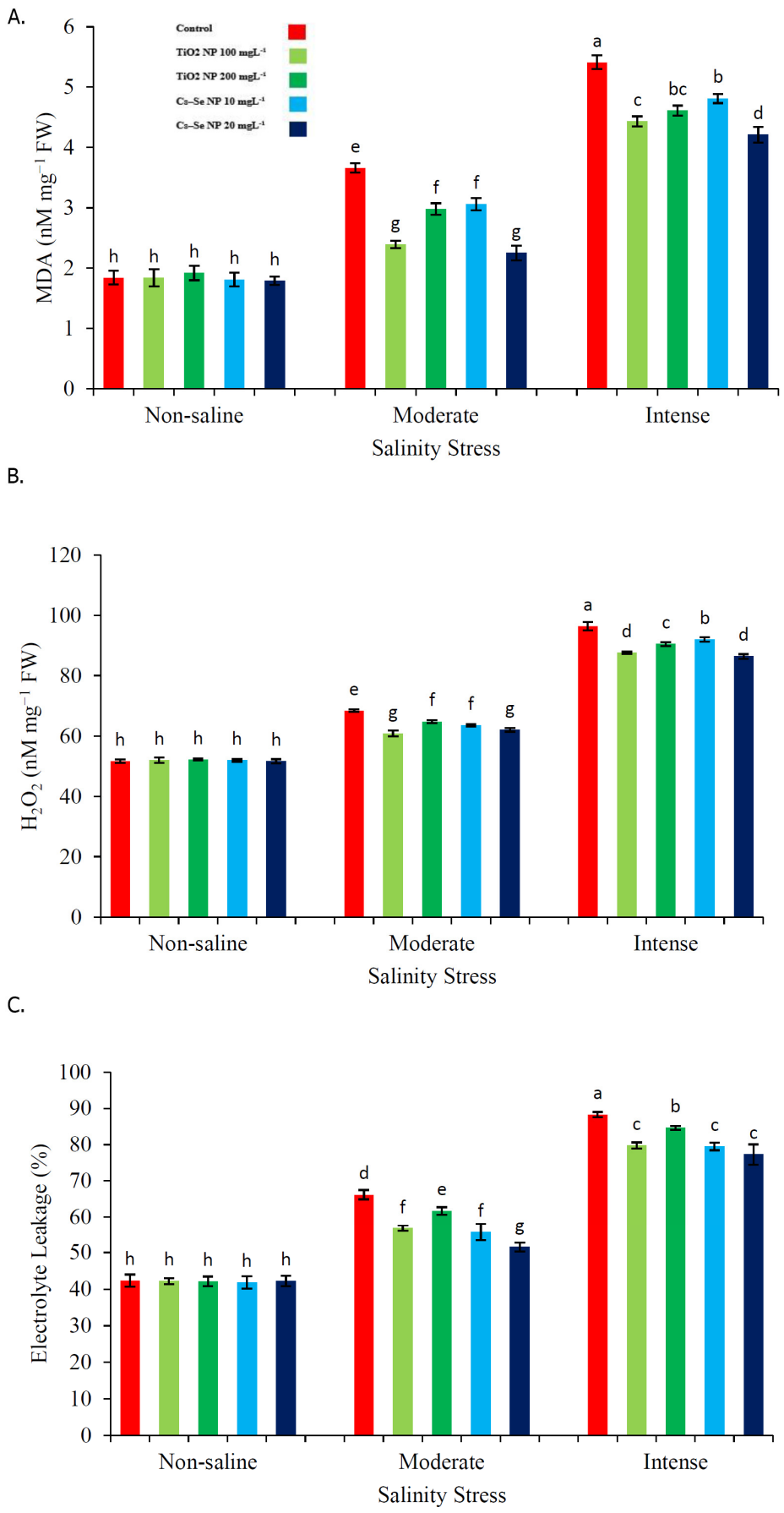

Figure 2. Effect of different concentrations of Cs-Se NPs and $\mathrm{TiO}_{2} \mathrm{NPs}$ on the content of MDA (A), $\mathrm{H}_{2} \mathrm{O}_{2}$ (B) and the electrolyte leakage (\%) parameter (C) of stevia (Stevia rebaudiana Bertoni) leaves under salinity stress. Data are the average of 3 repetitions \pm standard error. Different letters indicate significantly different values according to Duncan's post hoc analysis at $p<0.05$. 


\subsection{Effect of $\mathrm{Cs}-\mathrm{Se}$ NPs and $\mathrm{TiO}_{2}$ NPs on Total Phenolics Content and DPPH} Scavenging Activity

The application of Cs-Se NPs $\left(20 \mathrm{mg} \mathrm{L}^{-1}\right)$ significantly increased the total phenolics content $(3.24 \%$ and $5.07 \%)$ and total antioxidant capacity $(14.08 \%$ and $10.74 \%)$ as compared with the non-treated plants under the $50 \mathrm{mM}$ and $100 \mathrm{mM}$ levels of salinity (Figure 3). Similar to the Cs-Se NPs $\left(20 \mathrm{mg} \mathrm{L}^{-1}\right)$, the $\mathrm{TiO}_{2} \mathrm{NPs}\left(100 \mathrm{mg} \mathrm{L}^{-1}\right)$ treatments also significantly increased the total phenolics content $(3.97 \%$ and $4.63 \%)$ and DPPH radical scavenging activity $(9.85 \%$ and $7.30 \%)$ as compared with the non-treated plants under the $50 \mathrm{mM}$ and $100 \mathrm{mM}$ levels of salinity (Figure 3A,B).

A.

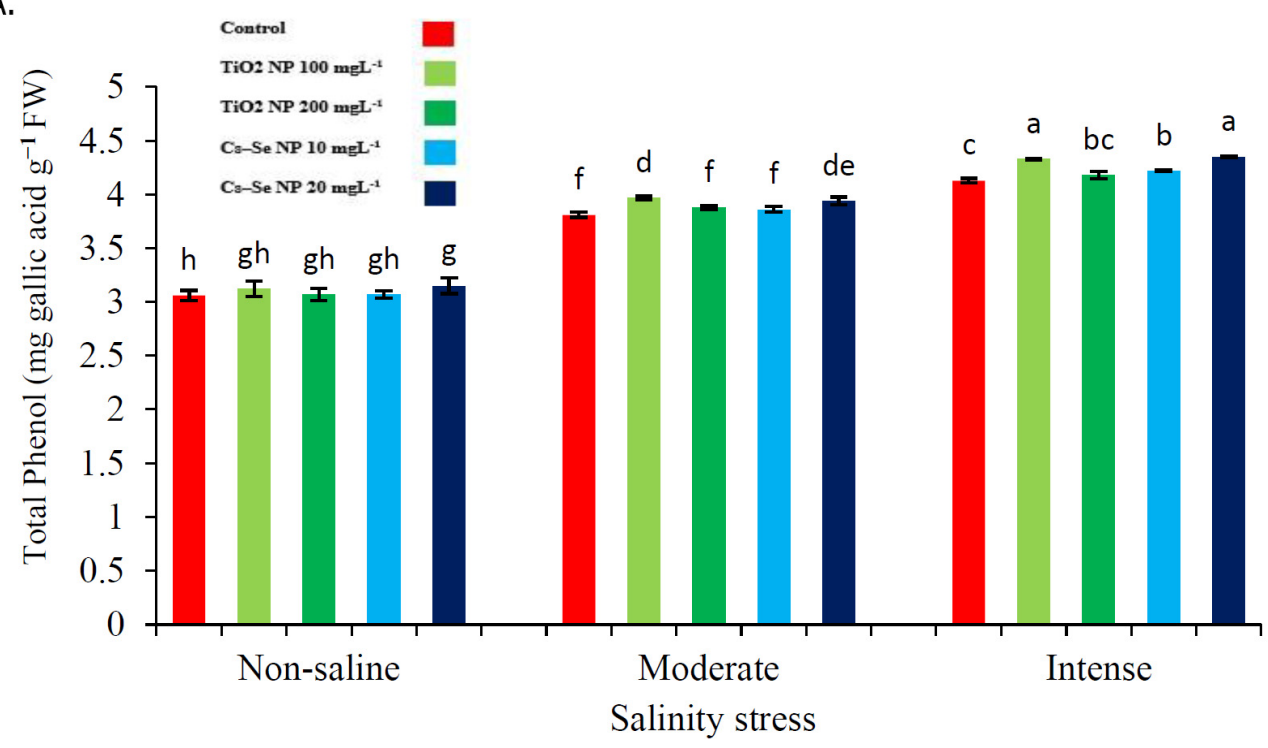

B.

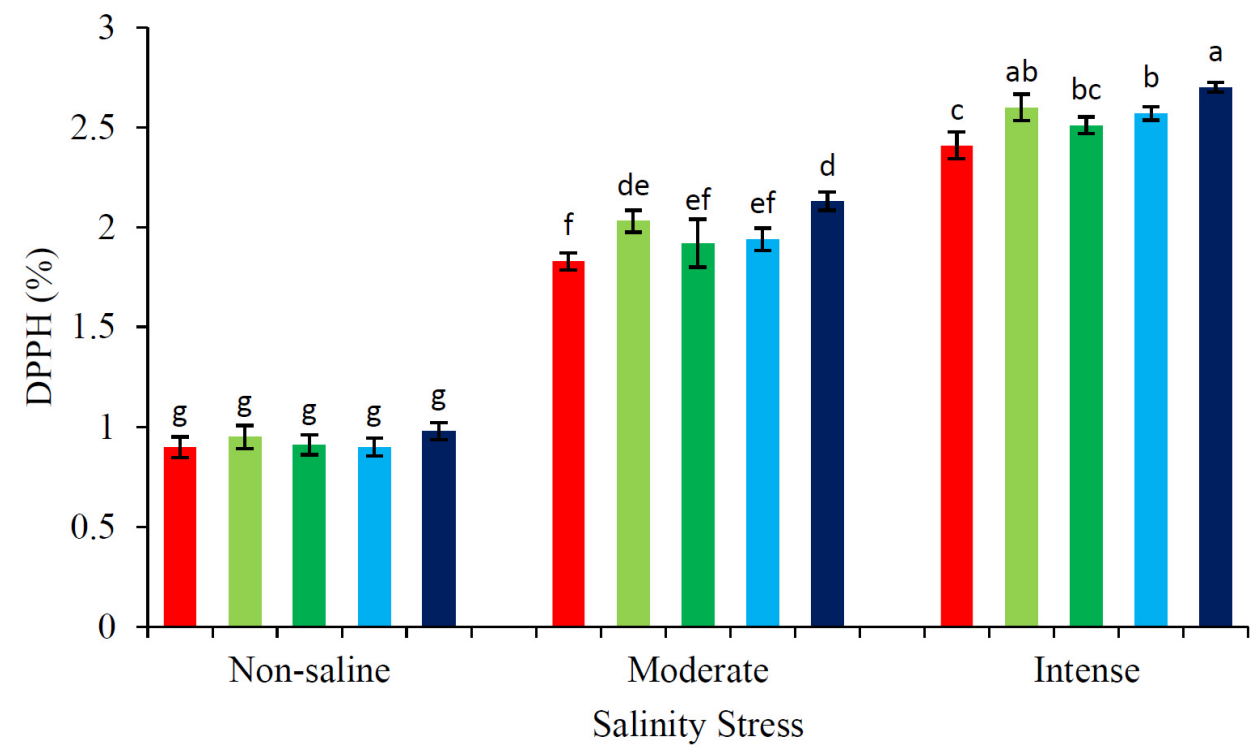

Figure 3. Effect of different concentrations of Cs-Se NPs and $\mathrm{TiO}_{2} \mathrm{NPs}$ on the Total Phenol (A) and total antioxidant capacity (B) of stevia (Stevia rebaudiana Bertoni) leaves under salinity Stress. Data are the average of 3 repetitions \pm standard error. Different letters indicate significantly different values according to Duncan's post hoc analysis at $p<0.05$. 


\subsection{Effect of $\mathrm{Cs}-\mathrm{Se} \mathrm{NPs}$ and $\mathrm{TiO}_{2} \mathrm{NPs}$ on Antioxidant Enzymes Activity}

Antioxidant enzymes protect cells from oxidative damage by eliminating excess reactive oxygen species in plants. Current findings showed that the application of Cs-Se NPs $\left(20 \mathrm{mg} \mathrm{L}^{-1}\right)$ significantly increased the CAT $(7.61 \%$ and $6.49 \%)$, APX $(11.67 \%$ and $7.12 \%)$, POD (17.17\% and $12.32 \%)$ and SOD (20.11\% and $14.69 \%)$ activity in comparison with non-treated plants under the $50 \mathrm{mM}$ and $100 \mathrm{mM}$ salinity levels. Moreover, $\mathrm{TiO}_{2} \mathrm{NPs}$ (100 $\mathrm{mg} \mathrm{L}^{-1}$ ) significantly improved the CAT (3.83\% and $\left.8.19 \%\right)$, POD $(18.30 \%$ and $9.85 \%)$ and SOD $(24.50 \%$ and $15.67 \%)$ activity as compared with the non-treated plants under the 50 and $100 \mathrm{mM} \mathrm{NaCl}$ conditions, respectively. In addition, $\mathrm{TiO}_{2} \mathrm{NPs}\left(100 \mathrm{mg} \mathrm{L}^{-1}\right)$ significantly increased APX $(9.96 \%)$ activity as compared with the non-treated plants under $100 \mathrm{mM} \mathrm{NaCl}$ (Figure 4A-D).

A.
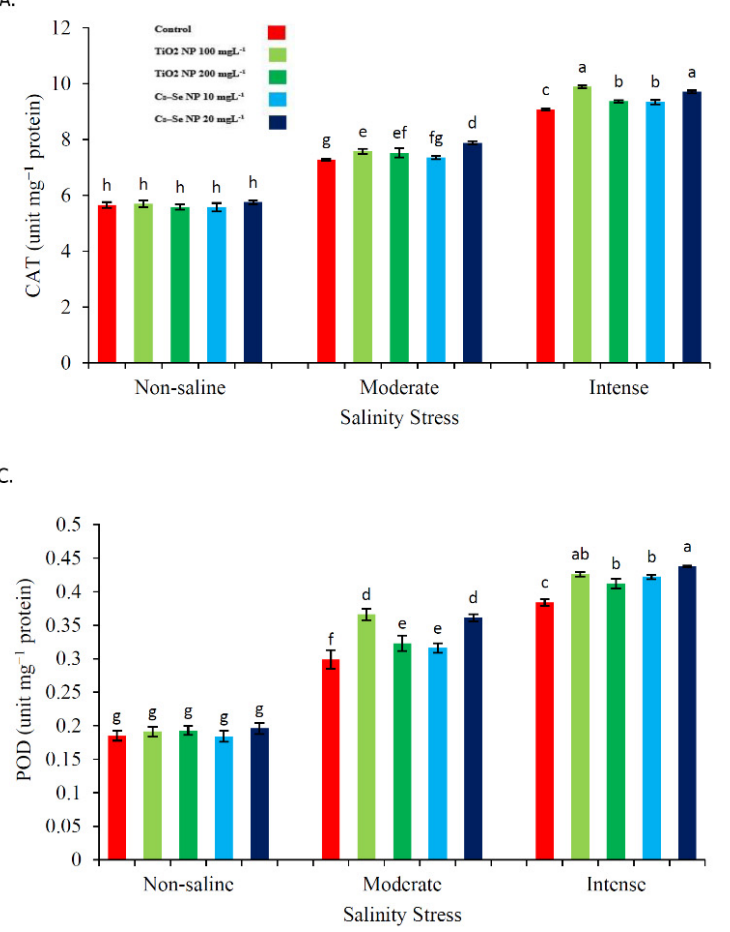

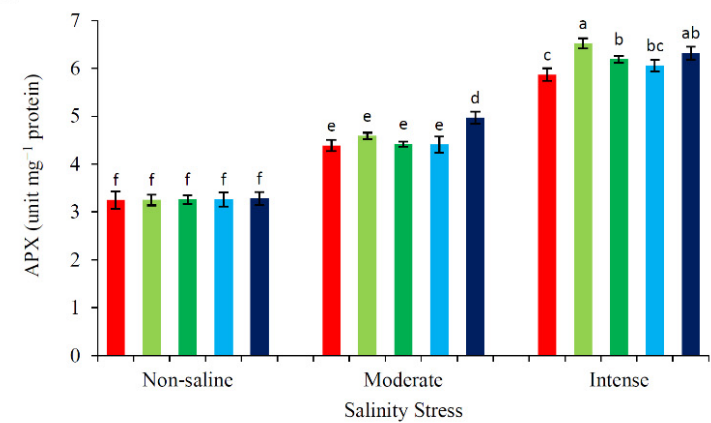

D.

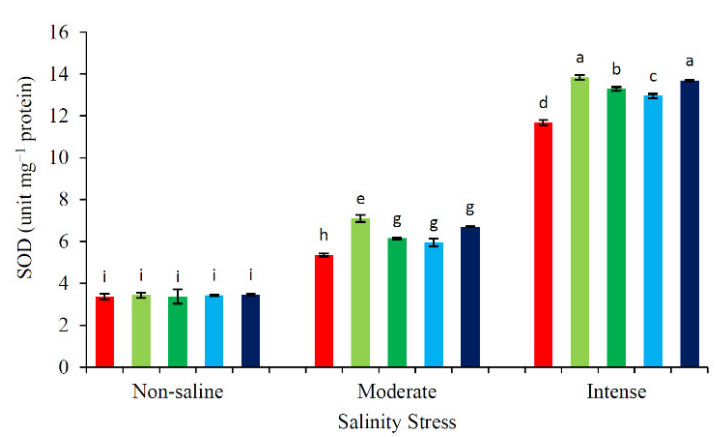

Figure 4. Effect of different concentrations of Cs-Se NPs and $\mathrm{TiO}_{2} \mathrm{NPs}$ on the CAT (A), APX (B), POD (C), and SOD (D) enzyme activities of stevia (Stevia rebaudiana Bertoni) leaves under salinity stress. Data are the average of 3 repetitions \pm standard error. Different letters indicate significantly different values according to Duncan's post hoc analysis at $p<0.05$.

\subsection{Effect of Cs-Se NPs and $\mathrm{TiO}_{2} \mathrm{NPs}$ on Essential Oil Content, as Well as Stevioside and Rebaudioside A Content}

Salinity and NP treatments significantly affected the essential oil content, as well as the stevioside and rebaudioside A contents (Figure 5). Increasing the salinity stress level led to an increase in essential oil content. The interactive effects of the major treatments on essential oil content were also found to be significant. Specifically, the findings revealed that Cs-Se NPs $\left(20 \mathrm{mg} \mathrm{L}^{-1}\right)$ increased the essential oil level the most $(10.00 \%$ and $2.87 \%)$ as compared with the non-treated plants under the $50 \mathrm{mM}$ and $100 \mathrm{mM}$ levels of salinity, respectively. Moreover, $\mathrm{TiO}_{2}$ NPs $\left(100 \mathrm{mg} \mathrm{L}^{-1}\right)$ significantly improved the essential oil content $(13.33 \%$ and $9.39 \%)$ as compared with the non-treated plants under the $50 \mathrm{mM}$ and $100 \mathrm{mM}$ saline conditions (Figure 5A). Regarding stevioside and rebaudioside A, the stevioside content increased with the severity of the stress, whilst rebaudioside A content increased up to $50 \mathrm{mM} \mathrm{NaCl}$ and then showed a decrease. In addition to the salt-stressinduced increases in stevioside content, Cs-Se NPs $\left(20 \mathrm{mg} \mathrm{L}^{-1}\right)$ treatments also significantly increased the stevioside content $(18.38 \%$ and $15.59 \%)$ and rebaudioside A content $(17.76 \%$ 
and $20.05 \%$ ) as compared with the non-treated plants under the $50 \mathrm{mM}$ and $100 \mathrm{mM}$ saline conditions, respectively. Similar to the treatment of Cs-Se NPs, the application of $\mathrm{TiO}_{2}$ NPs (100 mg L $\left.{ }^{-1}\right)$ significantly increased the stevioside content $(17.81 \%$ and $17.66 \%)$ and rebaudioside A content (14.61\% and $18.18 \%$ ) as compared with the non-treated plants under the $50 \mathrm{mM}$ and $100 \mathrm{mM}$ saline conditions, respectively (Figure 5B,C).

A.

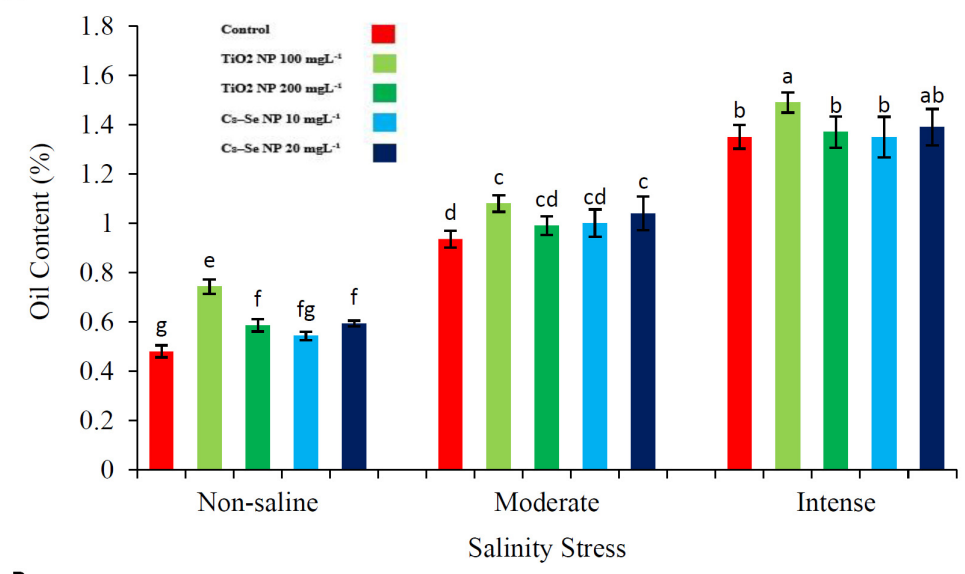

B.
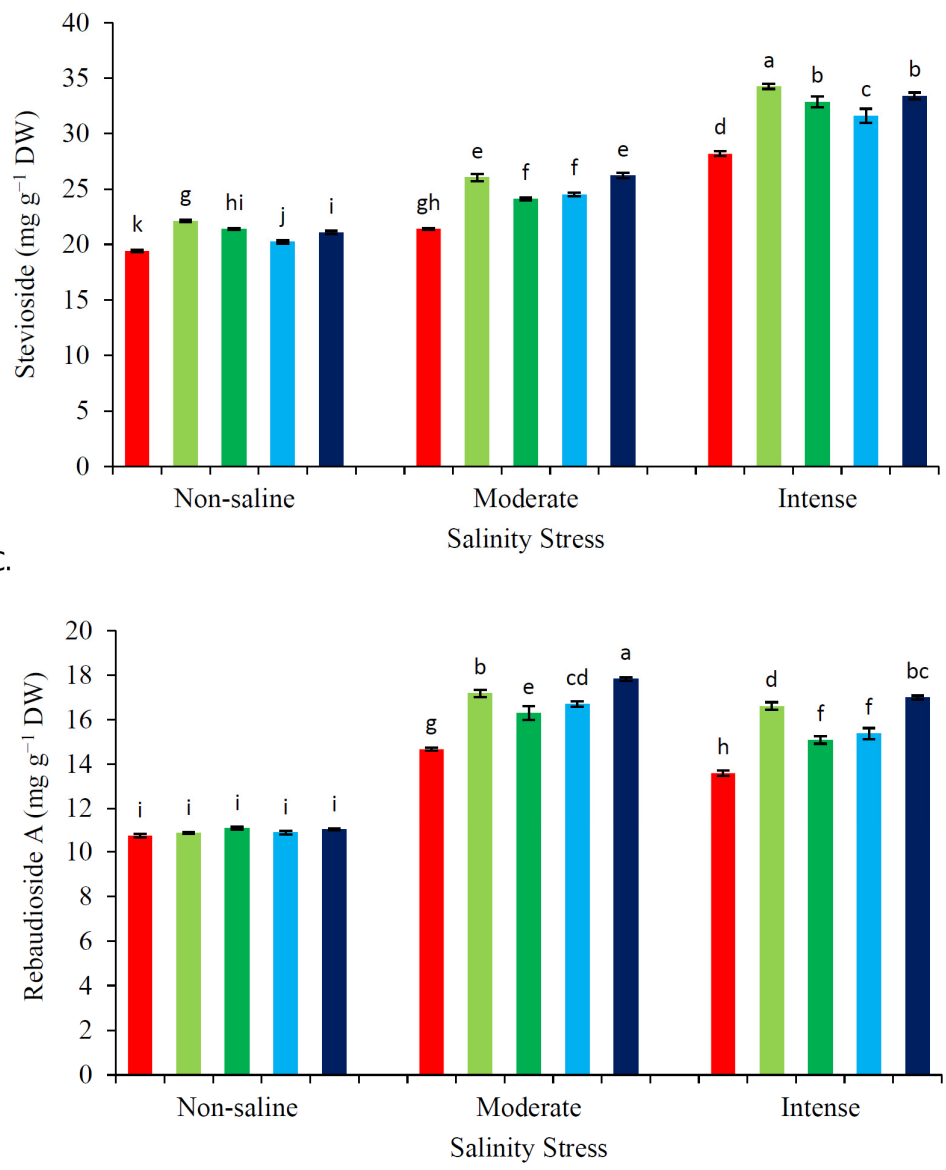

Figure 5. Effect of different concentrations of $\mathrm{Cs}-\mathrm{Se} \mathrm{NPs}_{\mathrm{s}}$ and $\mathrm{TiO}_{2} \mathrm{NPs}$ on the oil content (A), stevioside (B) and rebaudioside A (C) of stevia (Stevia rebaudiana Bertoni) leaves under salinity stress. Data are the average of 3 repetitions \pm standard error. Different letters indicate significantly different values according to Duncan's post hoc analysis at $p<0.05$. 


\subsection{Heat Map Clustering and Principal Component Analysis of the Examined Parameters}

Due to the large amounts of data about the examined parameters corresponding to the salt stress and NPs treatments, a heat map was constructed in order to clarify, visualize and correlate the relevant findings of the current study (Figure 6A). Based on the analysis results, the clustering revealed that different combinations of salt stress $\left(\mathrm{S}_{0}\right.$ : control, $\mathrm{S}_{1}$ :

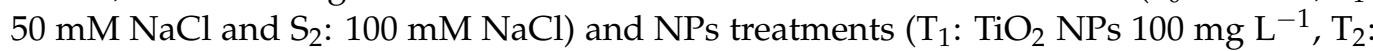

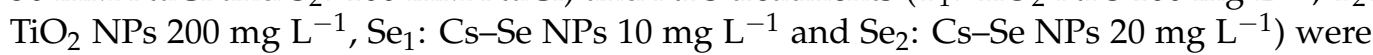
classified into two major groups. As part of the clustering, all salt stress groups were clearly classified. The first group was composed of the higher level of salt stress $\left(\mathrm{S}_{2}: 100 \mathrm{mM}\right.$ $\mathrm{NaCl}$ ), whilst the second group was composed of the control $\left(\mathrm{S}_{0}\right)$ and the lower level of salt stress $\left(\mathrm{S}_{1}: 50 \mathrm{mM} \mathrm{NaCl}\right)$. Interestingly, the scattering of the NPs was similar to the salt stress groups corresponding to the responses of stevia plants. Considering the examined parameters of the plant, two major clusters were also observed. The heat map clustering was supported by principal component analysis (PCA), with a high explained variance ratio of the components (accounting for $97.75 \%$ of the variability of the original data) (Figure 6B). As deduced from both the heat map and the PCA, the examined parameters were clearly sorted into two groups. The first group was regarded as the yield parameters and photosynthesis-related parameters, whilst the second group included stress-related physiological and biochemical parameters, as well as secondary metabolites. 
A.

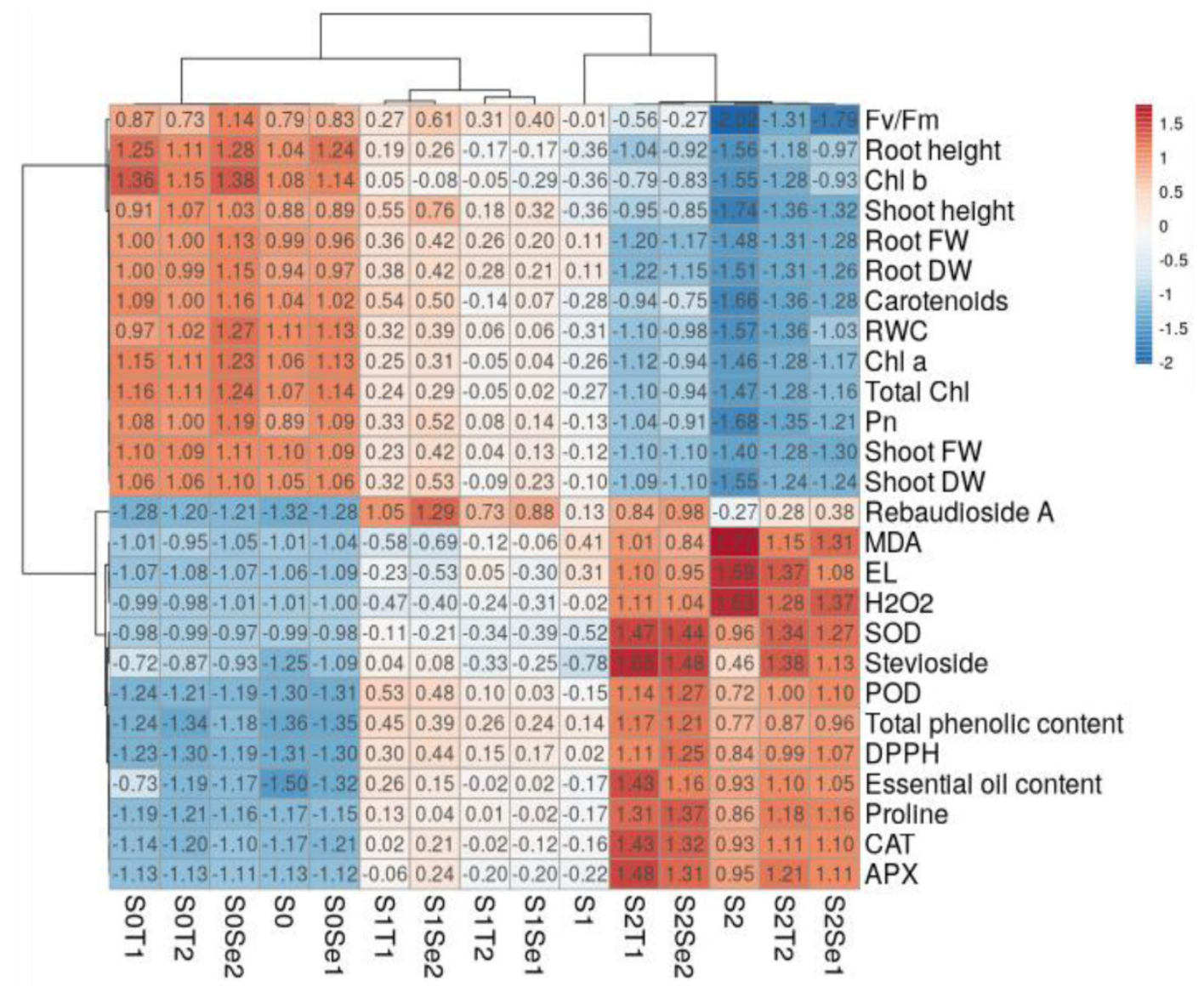

B.

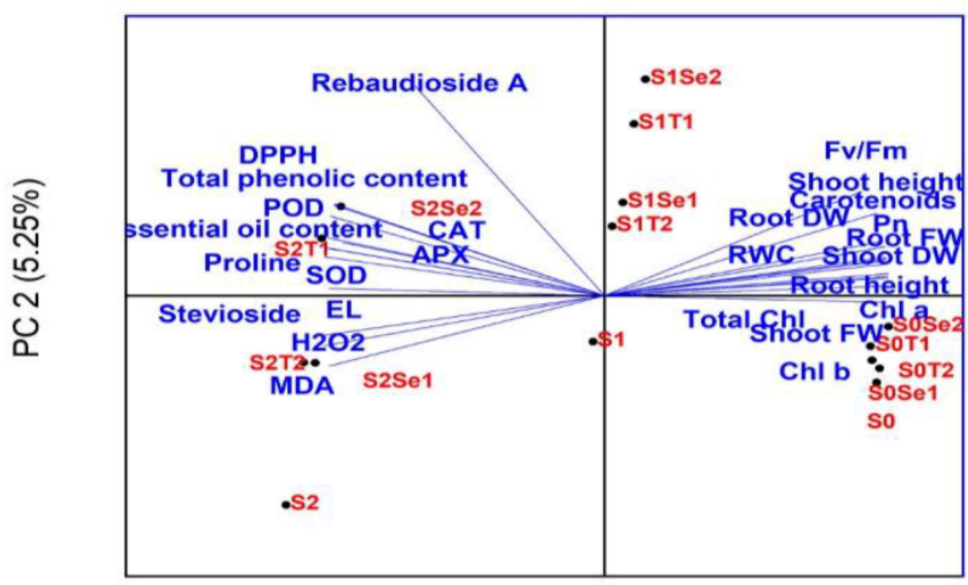

PC $1(92.50 \%)$

Figure 6. Heat map corresponding to the dependent and independent variables along with the treatments (A) and the principal component analysis regarding the observations $(\mathbf{B})$ of salinity and $\mathrm{TiO}_{2}$ and $\mathrm{Cs}-\mathrm{Se}$ nanoparticle applications on the examined traits in Stevia rebaudiana Bertoni $\left(\mathrm{S}_{0}: 0 \mathrm{mM} \mathrm{NaCl} ; \mathrm{S}_{0} \mathrm{Se}_{1}: 0 \mathrm{mM} \mathrm{NaCl}, 10 \mathrm{mg} \mathrm{L}^{-1} \mathrm{Cs}-\mathrm{Se} \mathrm{NPs} ; \mathrm{S}_{0} \mathrm{Se}_{2}: 0 \mathrm{mM} \mathrm{NaCl}_{2} 20 \mathrm{mg} \mathrm{L}^{-1}\right.$ Cs-Se NPs; $\mathrm{S}_{0} \mathrm{~T}_{1}: 0 \mathrm{mM} \mathrm{NaCl}, 100 \mathrm{mg} \mathrm{L}^{-1} \mathrm{TiO}_{2} \mathrm{NPs} ; \mathrm{S}_{0} \mathrm{~T}_{2}: 0 \mathrm{mM} \mathrm{NaCl}, 200 \mathrm{mg} \mathrm{L}{ }^{-1} \mathrm{TiO}_{2} \mathrm{NPs} ; \mathrm{S}_{1}: 50 \mathrm{mM} \mathrm{NaCl} ; \mathrm{S}_{1} \mathrm{Se}_{1}: 50 \mathrm{mM}$ $\mathrm{NaCl}, 10 \mathrm{mg} \mathrm{L}{ }^{-1}$ Cs-Se NPs; $\mathrm{S}_{1} \mathrm{Se}_{2}: 50 \mathrm{mM} \mathrm{NaCl}, 20 \mathrm{mg} \mathrm{L}^{-1}$ Cs-Se NPs; $\mathrm{S}_{1} \mathrm{~T}_{1}: 50 \mathrm{mM} \mathrm{NaCl}, 100 \mathrm{mg} \mathrm{L}^{-1} \mathrm{TiO}_{2} \mathrm{NPs}_{3} \mathrm{~S}_{1} \mathrm{~T}_{2}$ : $50 \mathrm{mM} \mathrm{NaCl}, 200 \mathrm{mg} \mathrm{L}^{-1} \mathrm{TiO}_{2} \mathrm{NPs} ; \mathrm{S}_{2}: 100 \mathrm{mM} \mathrm{NaCl} \mathrm{S}_{2} \mathrm{Se}_{1}: 100 \mathrm{mM} \mathrm{NaCl}, 10 \mathrm{mg} \mathrm{L}^{-1} \mathrm{Cs}-\mathrm{Se} \mathrm{NPs}_{2} \mathrm{~S}_{2} \mathrm{Se}_{2}: 100 \mathrm{mM} \mathrm{NaCl}$, $\left.20 \mathrm{mg} \mathrm{L}^{-1} \mathrm{Cs}-\mathrm{Se} \mathrm{NPs} ; \mathrm{S}_{2} \mathrm{~T}_{1}: 100 \mathrm{mM} \mathrm{NaCl}, 100 \mathrm{mg} \mathrm{L}^{-1} \mathrm{TiO}_{2} \mathrm{NPs}_{2} \mathrm{~S}_{2} \mathrm{~T}_{2}: 100 \mathrm{mM} \mathrm{NaCl}, 200 \mathrm{mg} \mathrm{L}^{-1} \mathrm{TiO}_{2} \mathrm{NPs}\right)$. 


\section{Discussion}

In the present study, the agronomic and biochemical responses of stevia grown under salt stress and Cs-Se NPs and $\mathrm{TiO}_{2} \mathrm{NPs}$ treatments were assessed. As previously reported for stevia, in particular $[30,34,36]$, salinity stress reduces agronomic parameters, such as shoot and root length, shoot and root fresh weight and shoot and root dry weight, but the application of Cs-Se NPs $\left(20 \mathrm{mg} \mathrm{L}^{-1}\right)$ and $\mathrm{TiO}_{2} \mathrm{NPs}\left(100 \mathrm{mg} \mathrm{L}^{-1}\right)$ positively regulates the relevant parameters (shoot and root length, shoot and root fresh weight and shoot and root dry weight). Improvement in plant growth parameters might be explained by the NPmediated enhancement in the performances of photosynthesis traits, such as chlorophyll $a$ and $b$, total chlorophyll, carotenoid content, Pn and Fv/Fm under salinity conditions, as deduced from the present findings. Regarding $\mathrm{TiO}_{2} \mathrm{NPs}$, the affirmative acts of the relevant NPs were also noted for Moldavian balm [25] and broad bean [28], which were correlated with the contribution to the chlorophyll development and Rubisco activities [37]. As formerly reported by Yang et al. [37] and Frazier et al. [38], the upregulation of gene expression and activity of Rubisco enzyme was provided by $\mathrm{TiO}_{2} \mathrm{NPs}$ treatments. Moreover, Tumburu et al. [39] reported that $\mathrm{TiO}_{2} \mathrm{NPs}$ increased the expression of genes related to photosynthetic metabolism in leaves of the Arabidopsis thaliana plant. $\mathrm{TiO}_{2} \mathrm{NPs}$ also increased photosynthesis parameters by increasing the light energy of the PSI absorbed by the chloroplast membrane to be transferred to PSII, the promotion of light energy conversion to electron energy and the electron transport and acceleration of water photolysis and oxygen evolution [40]. In addition to activation of the photosynthesis machinery of the plant, growth parameters are also positively correlated with the absorption of essential elements in the Cs-Se-NP- and $\mathrm{TiO}_{2}$-NP-treated plants under salinity conditions [27,41].

Considering Se NP applications, the current findings are consistent with the reports indicating that Se NPs significantly improved the growth and photosynthetic performances of strawberry [42] and tomato [43] plants under salinity stress conditions. As deduced from the former reports, $\mathrm{TiO}_{2} \mathrm{NPs}$ and Cs-Se NPs have a positive regulatory role on the photosynthetic system and growth parameters.

Munns and Tester [44] reported that reduced water uptake due to increased osmolarity of soil solution is one of the earliest effects of salinity on plants. However, the water balance of the plants can be maintained by increasing their osmolyte (e.g., proline) levels. In addition to the maintained water status of the cells, Shamsul et al. [45] reported that the overaccumulation of proline might provide several benefits concerned with scavenging ROS to prevent a sustained oxidative burst and stabilizing membranes to prevent electrolyte leakage. Along with the treatments of Cs-Se NPs $\left(20 \mathrm{mg} \mathrm{L}^{-1}\right)$ and $\mathrm{TiO}_{2} \mathrm{NPs}$ (100 mg L $\mathrm{L}^{-1}$ ), notable increases were recorded for the proline content and RWC in stevia. As is well-known, salinity causes substantial decreases in the assimilation, accumulation and metabolism of nitrogen, which has a key role in the biosynthesis of proline [46]. However, Se NPs and $\mathrm{TiO}_{2}$ NPs treatments might elevate the proline content in plants through increasing the activity of nitrate reductase (a key enzyme of nitrogen assimilation) $[29,37,47]$ and plant nitrogen status $[48,49]$. As in the case of enhanced growth parameters, current findings are also consistent with the reports indicating that the application of Cs-Se NPs [27], Se NPs [42] and $\mathrm{TiO}_{2}$ NPs [28] increased proline and RWC in bitter melon, strawberry and broad bean, respectively, under salinity stress conditions.

As is well reported for quite a number of plants, salinity stress causes excessive ROS production, which then attacks lipids, proteins, DNA and carbohydrates. Furthermore, an oxidative burst results in membrane lipid peroxidation (oxidative damages) and the production of MDA in plants [50]. In order to maintain their proper and sustainable development, plants have evolved two detoxification mechanisms, namely, enzymatic and non-enzymatic antioxidants defense mechanisms, in order to maintain ROS at safe levels. In this regard, CAT, SOD, POD and APX are some of the principal enzymatic antioxidants in plants [51], whilst phenolic compounds are one of the main non-enzymatic defense compounds [52]. As is well-documented in quite a number of studies, the total antioxidant capacity of plants is correlated with the phenolic contents available [53-56]. As in the 
current study, we observed that the application of Cs-Se NPs $\left(20 \mathrm{mg} \mathrm{L}^{-1}\right)$ and $\mathrm{TiO}_{2} \mathrm{NPs}$ (100 $\mathrm{mg} \mathrm{L}^{-1}$ ) significantly increased the total phenolics content; CAT, SOD, POD and APX activity; and total antioxidant capacity. The application of Se NPs $\left(20 \mathrm{mg} \mathrm{L}^{-1}\right)$ and $\mathrm{TiO}_{2} \mathrm{NPs}$ (100 mg L ${ }^{-1}$ ) also significantly decreased $\mathrm{H}_{2} \mathrm{O}_{2}$, MDA content and EL in the stevia plants under salinity conditions. As previously reported for bitter melon under salinity stress, CsSe NPs increased the total phenols; CAT, SOD, POD and APX activity; and total antioxidant capacity; and decreased the $\mathrm{H}_{2} \mathrm{O}_{2}$ and MDA content, as well as the EL [27]. Zahedi et al. [42] reported that Se NPs improved POD and SOD activity and decreased $\mathrm{H}_{2} \mathrm{O}_{2}$ and MDA levels in strawberries under salinity conditions. Moreover, Gohari et al. [25] observed that the application of $\mathrm{TiO}_{2}$ NPs increased the CAT, SOD, GP (guaiacol peroxidase) and APX activity and decreased $\mathrm{H}_{2} \mathrm{O}_{2}$ content in Moldavian balm plant under salinity conditions. In addition, Abdel Latef et al. [28] reported that the application of $\mathrm{TiO}_{2} \mathrm{NPs}_{\text {increased SOD }}$ and APX activity and decreased MDA content in broad bean plants under saline conditions. Considering the relevant findings of detoxification elements examined as part of this study, the increases in activity of the enzymes and phenolic contents might explain the improved physiology and agronomic traits of stevia.

Considering medicinal plants, the pharmaceutical activities or biological activities of these relevant plant species are dependent on the metabolites available [57-59]. In this regard, to increase or to keep the desired level of the medicinally important metabolites is one of the great interests of stevia researchers $[30,32,60]$. Out of the medicinal plants defined, stevia is one of the reputed medicinal plants used in the pharmaceutical industry, with it being well-known for its diabetes-controlling properties. Stevioside and rebaudioside A are the most important compounds of stevia. Steviol glycoside is a group of secondary metabolites that are derived from the mono-, di- and tetra-terpene biosynthetic pathways. The major steviol glycosides, such as stevioside and rebaudioside $\mathrm{A}$, are non-caloric sweeteners that are used in many countries due to being sweeter than sucrose [61]. In this context, any exogenous treatments for stimulating the production of these metabolites might be of great interest to stevia growers. Along with the present study, we observed an increase in stevioside content but a decrease in rebaudioside A content under severe salt stress. Of the available reports with respect to the impacts of salt stress on stevioside and rebaudioside A content, Zeng et al. [30] showed that salt stress reduced the content of stevioside and rebaudioside A, whilst Cantabella et al. [32] reported that salinity increased rebaudioside A content in stevia plants. Moreover, osmoprotectant functions of those metabolites were reported under salt stress [32] and water stress [61]. In this study, we also recorded a substantial increase in stevioside content under severe saline conditions, which are consistent with the previous reports [32,61]. Regarding this study, the application of Cs-Se NPs $\left(20 \mathrm{mg} \mathrm{L}^{-1}\right)$ and $\mathrm{TiO}_{2} \mathrm{NPs}\left(100 \mathrm{mg} \mathrm{L}^{-1}\right)$ significantly increased the stevioside and rebaudioside A contents. In addition to these metabolites, the relevant NP treatments also augmented the essential oil content of stevia. In the report by Sheikhalipour et al. [27], Cs-Se NPs increased the essential oil content in bitter melon fruits under salinity conditions. Moreover, $\mathrm{TiO}_{2} \mathrm{NPs}$ increased the essential oil content in Salvia officinalis [62], Mentha piperita [63] and Moldavian balm [25]. In addition, the application of Se NPs increased the synthesis of secondary metabolites through increases in the expression of biosynthesis pathway-related genes: Pal, 4CL, HCT, pAmt, Kas, Acl, Fat and AT3 in pepper [64], and Pal and 4CL in bitter melon plant [65]. The modulator roles of NPs on the pathways of plant secondary metabolites are not well-explained hitherto even though in this regard, Marslin et al. [66] postulated that the penetration and/or fixation of NPs on the cell surface and/or within cells causes elevated levels of ROS. Subsequently, cytoplasmic $\mathrm{Ca}^{2+}$, antioxidant system and mitogen-activated protein kinase (MAPK) cascades trigger transcriptional reprogramming of relevant genes involved in secondary metabolism. 


\section{Materials and Methods}

\subsection{Preparation of Titanium Dioxide Nanoparticles and Selenium Functionalized Using} Chitosan Nanoparticles

The synthesis and characterization of the selenium functionalized using chitosan nanoparticles (Cs-Se NPs) and titanium dioxide nanoparticles $\left(\mathrm{TiO}_{2} \mathrm{NPs}\right)$ used in this experiment are described in Sheikhalipour et al. [27] and Gohari et al. [25]. The synthesis was carried out in a nanochemistry laboratory, University of Maragheh, Iran. Regarding the characterization results, the sizes of the Cs-Se and $\mathrm{TiO}_{2} \mathrm{NPs}_{\mathrm{N}}$ were $60 \mathrm{~nm}$ and $25 \mathrm{~nm}$, respectively.

\subsection{Plant Material and Treatments}

The experiment was conducted in the research greenhouses of the Faculty of Agriculture, Mohaghegh Ardabili University $\left(46^{\circ} 16^{\prime} \mathrm{E}, 37^{\circ} 23^{\prime} \mathrm{N}\right.$, altitude $\left.1485 \mathrm{~m}\right)$, as a factorial experiment using a random design. As a plant material, vegetatively propagated Stevia rebaudiana Bertoni cuttings with three fully-developed leaves were obtained from Pakanbazr Company, Isfahan, Iran. The seedlings were transferred to main pots $(40 \mathrm{~cm} \times 15 \mathrm{~cm})$ containing coco peat and perlite $(2: 1, v / v)$ and uniformly irrigated with tap water each day for one week, then fertigated with half-strength Hoagland's nutrient solution every 2 days until harvest. Thereafter, the plants were continuously watered with full-strength Hoagland's nutrient solution supplemented with $\mathrm{NaCl}$ at concentrations of 0,50 and $100 \mathrm{mM}$ (nonsaline conditions, moderate and intense stress) two weeks after being transferred to the main pots, which continued up to plant harvest (prolonged stress of approximately forty days after applying salt stress). To prevent the accumulation of salt in the culture medium, the culture medium was washed once a week with tap water. After two weeks from the beginning of salinity stress, the plants were sprayed with selenium nanoparticles (Cs-Se NPs) at concentrations of 0,10 and $20 \mathrm{mg} \mathrm{L}^{-1}$ and anatase titanium dioxide nanoparticles $\left(\mathrm{TiO}_{2} \mathrm{NPs}\right.$ ) at concentrations of 0,100 and $200 \mathrm{mg} \mathrm{L}^{-1}$. Selenium nanoparticles (Cs-Se $\mathrm{NPs}$ ) and titanium dioxide nanoparticles $\left(\mathrm{TiO}_{2} \mathrm{NPs}\right.$ ) were applied once a week during the growth period (three times). All treatments were dispersed in deionized water (DIW) and then Tween 20 (Sigma-Aldrich Co, St. Louis, MO, USA) was added to the suspension and foliar application was performed. This experiment was performed in three repetitions and there were three plants in each repetition ( 9 plants for each treatment). The greenhouse temperatures of $26 / 19 \pm 4{ }^{\circ} \mathrm{C}$ (day/night) and air relative humidity of ca. $80 \pm 5 \%$ were maintained throughout the experiment under natural light and length of the day.

\subsection{Plant Growth and Relative Water Content (RWC) in Leaves}

Shoot and root height were recorded at the harvest stage. The fresh weight (FW) of the shoots and roots was recorded at harvest and the shoot and root dry weight (DW) was measured after samples were oven-dried (UFP800, Memmert, Büchenbach, Germany) at $70{ }^{\circ} \mathrm{C}$ for $72 \mathrm{~h}$. The RWCs of leaves in treated and non-treated plants were determined using the method of Sairam and Srivastava [67].

\subsection{Photosynthetic Pigments, Gas Exchange Capacity and Chlorophyll Fluorescence}

Chlorophyll $a(\mathrm{Chl} a)$ and chlorophyll $b(\mathrm{Chl} b)$, total chlorophyll and carotenoids (Car) were extracted from fresh leaves $(0.2 \mathrm{~g})$ using $80 \%(v / v)$ acetone. After centrifugation $\left(15,000 \times g\right.$ for $5 \mathrm{~min}$ at $\left.25^{\circ} \mathrm{C}\right)$, the absorbance for each extract was spectrophotometrically recorded at 470, 646 and $663 \mathrm{~nm}$ (UV-1800 Shimadzu, Kyoto, Japan), and the concentration of photosynthetic pigments was determined using the following equations from Arnon [68]:

$$
\begin{gathered}
\text { Chl } a=(12.47 \times \mathrm{A} 663)-(3.62 \times \mathrm{A} 645) \\
\text { Chl } b=(25.06 \times \mathrm{A} 645)-(6.5 \times \mathrm{A} 663) \\
\text { Carotenoids }=(1000 \times \mathrm{A} 470)-(1.29 \mathrm{Chl} a-53.78 \mathrm{Chl} b)
\end{gathered}
$$


Photosynthetic rates (Pn) of leaves at the second or third nodes of the plants were measured using an infrared (IR) gas analyzer (LI-6400T, Li-Cor Inc., Lincoln, NE, USA), with a red/blue light source (6400-02B) [69]. The chlorophyll fluorescence parameter (Fv/Fm) was measured using a DUAL-PAM-100 chlorophyll fluorometer (Heinz Walz, Efeltrich, Germany) after the adaption of stevia in the dark for $30 \mathrm{~min}$. Chlorophyll fluorescence was determined on sunny days between 8:00 $\mathrm{h}$ and 9:00 $\mathrm{h} \mathrm{[70].}$

\subsection{Proline, Malondialdehyde (MDA) and Hydrogen Peroxide $\left(\mathrm{H}_{2} \mathrm{O}_{2}\right)$ Contents and Electrolyte Leakage (EL)}

The leaf proline content was quantified according to the method of Bates et al. [71]. Briefly, fresh leaves were homogenized in a 3\% sulfosalicylic acid solution. Then, the homogenates were centrifuged at $15,000 \times \mathrm{g}$ for $10 \mathrm{~min}$ at $4{ }^{\circ} \mathrm{C}$. After centrifugation, $1 \mathrm{~mL}$ of the supernatant was placed in a tube and was allowed to react with $1 \mathrm{~mL}$ acid ninhydrin and $1 \mathrm{~mL}$ of glacial acetic acid. The relevant mixture was heated at $100{ }^{\circ} \mathrm{C}$ for $60 \mathrm{~min}$. The reaction was terminated by placing the mixture on ice, then $2 \mathrm{~mL}$ of toluene was used for extracting the reaction mixture. The separation of the two phases was carried out after keeping the samples at room temperature for $30 \mathrm{~min}$. Finally, the absorbances of the upper phase were read using a spectrophotometer at $520 \mathrm{~nm}$ and toluene was used as the blank.

Lipid peroxidation was measured using the amount of malondialdehyde (MDA) [72]. The samples of fresh leaf tissue $(0.3 \mathrm{~g})$ were ground in $20 \%$ trichloroacetic acid and centrifuged at $13,000 \mathrm{rpm}$ for $15 \mathrm{~min}$ and $4 \mathrm{~mL}$ of $20 \%$ TCA were added to $1 \mathrm{~mL}$ of the supernatant. The mixtures were heated for $30 \mathrm{~min}$ in a hot water bath $\left(95^{\circ} \mathrm{C}\right)$ and were thereafter immediately cooled in an ice bath. Malondialdehyde content was determined at two wavelengths of 532 and $600 \mathrm{~nm}$. To calculate the MDA concentration, a molar absorption coefficient of $155 \mathrm{mM}^{-1} \mathrm{~cm}^{-1}$ was used.

For the quantification of hydrogen peroxide $\left(\mathrm{H}_{2} \mathrm{O}_{2}\right)$, the method proposed by Alexieva et al. [73] was employed, where hydrogen peroxide was measured spectrophotometrically after reacting with $\mathrm{KI}$. The reaction mixture consisted of $0.5 \mathrm{~mL} 0.1 \%$ trichloroacetic acid (TCA) leaf extract supernatant, $0.5 \mathrm{~mL}$ of $100 \mathrm{mM}$ K-phosphate buffer and $2 \mathrm{~mL}$ reagent ( $1 \mathrm{MKI} w / v$ in fresh double-distilled water). The blank probe consisted of $0.1 \%$ TCA in the absence of leaf extract. The reaction was developed for $1 \mathrm{~h}$ in darkness and the absorbance was measured at $390 \mathrm{~nm}$. The amount of hydrogen peroxide was calculated using a standard curve prepared with known concentrations of $\mathrm{H}_{2} \mathrm{O}_{2}$.

Electrolyte leakage, as an indicator of stress damage, was determined according to Nanjo et al. [74]. Samples were kept in falcons comprising $10 \mathrm{~mL}$ of distilled water at room temperature $\left(25^{\circ} \mathrm{C}\right)$ and shook for $24 \mathrm{~h}$ at $120 \mathrm{rpm}$. The primary electrical conductivity of solution $\left(\mathrm{EC}_{1}\right)$ was recorded. The electrolytes of the tissue were released by autoclaving the same samples at $100{ }^{\circ} \mathrm{C}$ for $2 \mathrm{~h}$. Then, the solution was cooled at room temperature and the electrical conductivity of the solution $\left(\mathrm{EC}_{2}\right)$ was registered. The relative electrolyte leakage $\mathrm{EC}_{1} / \mathrm{EC}_{2} \times 100$ was recorded.

\subsection{Antioxidant Enzymes}

Fresh leaf samples $(0.5 \mathrm{~g})$ were homogenized in $5 \mathrm{~mL}$ of $0.05 \mathrm{M}$ phosphate buffer $(1 \mathrm{mM}$ EDTA, $1 \%$ PVP, pH 7.8) and the homogenates were centrifuged at $12,000 \times g$ for $20 \mathrm{~min}$ at $4{ }^{\circ} \mathrm{C}$. The supernatants were collected and used for the determination of peroxidase (POD), ascorbate peroxidase (APX), catalase (CAT) and superoxide dismutase (SOD) activity. The activity of POD was measured using the method of Hemeda and Klein [75]. To determine the peroxidase activity, a reaction mixture containing enzyme extract, $100 \mathrm{mM}$ potassium phosphate buffer ( $\mathrm{pH} 6.0), 5 \mu \mathrm{L}$ of $10 \%(w / v) \mathrm{H}_{2} \mathrm{O}_{2}$ and $16 \mathrm{mM}$ guaiacol was used. The enzyme activity was expressed at $470 \mathrm{~nm}$ for $1 \mathrm{~min}$ as millimoles of produced tetraguaiacol per minute per milligram of soluble protein $\left(\mathrm{U} \mathrm{mg}^{-1}\right)$. The activity of CAT was measured using the method of Aebi [76]. The reaction mixture contained $25 \mathrm{mM}$ phosphate buffer ( $\mathrm{pH}$ 6.8) and $10 \mathrm{mM} \mathrm{H}_{2} \mathrm{O}_{2}$. The reduction at $240 \mathrm{~nm}$ was registered. The activity of SOD was measured using the method of Giannopolitis and Ries [77]. One unit of SOD activity was defined as the amount of enzyme required to cause $50 \%$ inhibition of the reduction 
rate of NBT (nitro blue tetrazolium) at $560 \mathrm{~nm}$. The activity of APX was measured using the method of Nakano and Asada [78]. To determine the ascorbate peroxidase activity, the reaction mixture contained enzyme extract, $50 \mathrm{mM}$ phosphate buffer ( $\mathrm{pH} 7.0), 0.5 \mathrm{mM}$ AsA, $1 \mathrm{mM} \mathrm{H}_{2} \mathrm{O}_{2}$ and $0.1 \mathrm{mM}$ EDTA. The reaction was started via the addition of $\mathrm{H}_{2} \mathrm{O}_{2}$ and the reduction in absorbance at $290 \mathrm{~nm}$ was recorded for $1 \mathrm{~min}$.

\subsection{Extraction and Quantification of Total Phenolics Content and Radical Scavenging Activity (DPPH)}

The air-dried and powdered samples $(0.5 \mathrm{~g})$ were extracted using $3 \mathrm{~mL} 85 \%(w / w)$ methanol and then centrifuged at $12,000 \times g$ for $15 \mathrm{~min}$. This methanolic extract was used to measure the total phenolic content and radical scavenging activity (DPPH). The total phenolic concentration was assayed used the Folin-Ciocalteu reagent, as described by Chun et al. [79]. For the total antioxidant capacity assay, the DPPH scavenging activities of the extracts were determined according to the method proposed by Suja et al. [80], which involved preparing a $0.1 \mathrm{mM}$ solution of 2.2-diphenyl-1-picrylhydrazyl (DPPH) in absolute ethanol. The antioxidant activity (\%) was determined using the following formula: $A_{0}-A_{1} / A_{0} \times 100$, where $A_{0}$-the absorbance of the control and $A_{1}$ - the absorbance of the standard.

\subsection{Stevioside, Rebaudioside A and Essential Oil Contents}

The contents of essential oils ( $\mathrm{mL} 100 \mathrm{~g}^{-1} \mathrm{FW}$ ) were measured in a Clevenger-type apparatus. A total of $0.1 \mathrm{~g}$ of powdered dried leaves were transferred to $15 \mathrm{~mL}$ tubes, $3 \mathrm{~mL}$ distilled water was added and the mixture was kept in a water bath for $30 \mathrm{~min}$ at $80{ }^{\circ} \mathrm{C}$. The resultant solution was firstly centrifuged at $12,000 \times g$ for $5 \mathrm{~min}$ and the supernatant was recovered (this process was repeated three times). The volume of the final supernatant was diluted to exactly $10 \mathrm{~mL}$ using distilled water and filtered using a $0.45 \mathrm{~m}$ nylon filter attached to a syringe. Then, the quantifications of the stevioside and rebaudioside A were performed using HPLC (Unicam Crystal 200, Thermo Fisher, UK) with a diode array detector based on the method of Martins et al. [81]. The main part of the mobile phase consisted of acetonitrile $(80 \% w / w)$ buffered to $\mathrm{pH}=0.5$ with $100 \mathrm{~mL}$ of $0.02 \mathrm{M}$ glacial acetic acid and $200 \mathrm{~mL}$ of $0.1 \mathrm{M}$ sodium hydroxide for every $500 \mathrm{~mL}$ of the total solvent. The injection volume of $5 \mathrm{~mL}$ and a constant flow rate of $0.7 \mathrm{~mL} / \mathrm{min}$ were programmed to flow through the Agilent Zorbax column $(250 \mathrm{~mm} \times 9 \mathrm{~mm} \times 4.6 \mathrm{~mm}$, $51 \mathrm{~min}$ ) in gradient mode varying from 10:90 to 90:10 $v / v$ following the detection using UV at $210 \mathrm{~nm}$.

\subsection{Statistical Analysis}

Data were analyzed by using SPSS 20.0 software and all data were statistically analyzed using Duncan's multi-range test with $p<0.05$ as the significant difference level. Moreover, a principal component analysis (PCA) was performed in order to discriminate the treatments of nanoparticles and salinity on the basis of agronomic traits, physiological attributes, enzymatic activities and the contents of stevioside and rebaudioside A (OriginLab Software). Furthermore, a heat map corresponding to the findings from the treatments was constructed for visualizing and relating the dependent and independent variables (ClustVis).

\section{Conclusions}

Nanotechnology is a new method for increasing plant tolerance against biotic and abiotic stresses. The results of this experiment showed that the application of $\mathrm{TiO}_{2} \mathrm{NPs}_{\text {and }}$ Cs-Se NPs increased the growth parameters by increasing photosynthetic parameters under salinity stress conditions. Moreover, the application of $\mathrm{TiO}_{2} \mathrm{NPs}$ and $\mathrm{Cs}-\mathrm{Se} \mathrm{NPs}$ increased the proline content, which led to an increase in the RWC in the plants. Furthermore, the application of $\mathrm{TiO}_{2}$ NPs and Cs-Se NPs reduced the oxidative damage in the plants through increased enzymatic activity and non-enzymatic antioxidants compound content in stevia under salt stress conditions. Finally, the application of $\mathrm{TiO}_{2} \mathrm{NPs}$ and Cs-Se NPs 
increased the essential oil content and concentration of stevioside (in non-saline and saline conditions) and rebaudioside A (under saline conditions) in stevia plants. Generally, the application of $\mathrm{TiO}_{2}$ NPs $\left(100 \mathrm{mg} \mathrm{L}^{-1}\right)$ and Cs-Se NPs $\left(20 \mathrm{mg} \mathrm{L}^{-1}\right)$ increased the measured traits of stevia more than $\mathrm{TiO}_{2}$ NPs $\left(200 \mathrm{mg} \mathrm{L}^{-1}\right)$ and Cs-Se NPs $\left(10 \mathrm{mg} \mathrm{L}^{-1}\right)$. Therefore, the use of $\mathrm{TiO}_{2}$ NPs $\left(100 \mathrm{mg} \mathrm{L}^{-1}\right)$ and Cs-Se NPs $\left(20 \mathrm{mg} \mathrm{L}^{-1}\right)$ might be regarded as a useful strategy for increasing growth, antioxidant activity, essential oil content and steviol glycosides concentration in stevia under saline conditions.

Author Contributions: Conceptualization, B.E. and G.G.; methodology, M.S. and G.G.; validation, M.S., G.G. and M.H.; formal analysis, M.S., H.F. and H.J.; data curation, M.S. and M.K.; writingoriginal draft preparation, M.S., M.H. and G.G.; writing—review and editing, G.G., M.H., M.K. and A.K.; supervision, B.E. and G.G.; project administration, B.E.; funding acquisition, B.E., G.G. and A.K. All authors have read and agreed to the published version of the manuscript.

Funding: We are thankful to the University of Mhaghighi for their kind support during this project. The authors also acknowledge the support from the University of Agriculture in Krakow, Poland, and the Ministry of Education and Science of the Republic of Poland.

Institutional Review Board Statement: Not applicable.

Informed Consent Statement: Not applicable.

Data Availability Statement: The data that support the findings of this study are available from the corresponding author upon reasonable request.

Acknowledgments: We would like to thank the University of Mohaghegh Ardabili, Ardabil, Iran, and the University of Agriculture in Krakow, Poland, for their kind support during this project.

Conflicts of Interest: The authors declare no conflict of interest.

Sample Availability: Samples of the compounds are available from the authors.

\section{References}

1. Azarmi-Atajan, F.; Sayyari-Zohan, M.H. Alleviation of salt stress in lettuce (Lactuca sativa L.) by plant growth-promoting rhizobacteria. J. Hortic. Postharvest Res. 2020, 3, 67-78.

2. El Moukhtari, A.; Cabassa-Hourton, C.; Farissi, M.; Savouré, A. How does proline treatment promote salt stress tolerance during crop plant development? Front. Plant Sci. 2020, 11, 1127. [CrossRef] [PubMed]

3. Moncada, A.; Vetrano, F.; Miceli, A. Alleviation of salt stress by plant growth-promoting bacteria in hydroponic leaf lettuce. Agronomy 2020, 10, 1523. [CrossRef]

4. Parihar, P.; Singh, S.; Singh, R.; Singh, V.P.; Prasad, S.M. Effect of salinity stress on plants and its tolerance strategies: A review. Environ. Sci. Pollut. Res. Int. 2015, 22, 4056-4075. [CrossRef]

5. Arif, Y.; Singh, P.; Siddiqui, H.; Bajguz, A.; Hayat, S. Salinity induced physiological and biochemical changes in plants: An omic approach towards salt stress tolerance. Plant Physiol. Biochem. 2020, 156, 64-77. [CrossRef] [PubMed]

6. Cheng, Y.W.; Kong, X.W.; Wang, N.; Wang, T.T.; Chen, J.; Shi, Z.Q. Thymol confers tolerance to salt stress by activating anti-oxidative defense and modulating $\mathrm{Na}^{+}$homeostasis in rice root. Ecotoxicol. Environ. Saf. 2020, 188, 109894. [CrossRef] [PubMed]

7. Munns, R.; Passioura, J.B.; Colmer, T.D.; Byrt, C.S. Osmotic adjustment and energy limitations to plant growth in saline soil. New Phytol. 2020, 225, 1091-1096. [CrossRef]

8. Qian, R.; Ma, X.; Zhang, X.; Hu, Q.; Liu, H.; Zheng, J. Effect of exogenous spermidine on osmotic adjustment, antioxidant enzymes activity, and gene expression of Gladiolus gandavensis seedlings under salt stress. J. Plant Growth Regul. 2020, 1-15. [CrossRef]

9. Kibria, M.G.; Hoque, M.A. A review on plant responses to soil salinity and amelioration strategies. Open J. Soil Sci. 2019, 9, 219-231. [CrossRef]

10. Singh, R.P.; Handa, R.; Manchanda, G. Nanoparticles in sustainable agriculture: An emerging opportunity. J. Control Release 2021, 329, 1234-1248. [CrossRef]

11. Zhao, L.; Lu, L.; Wang, A.; Zhang, H.; Huang, M.; Wu, H.; Xing, B.; Wang, Z.; Ji, R. Nano-biotechnology in agriculture: Use of nanomaterials to promote plant growth and stress tolerance. J. Agric. Food Chem. 2020, 68, 1935-1947. [CrossRef]

12. Hawrylak-Nowak, B.; Hasanuzzaman, M.; Matraszek-Gawron, R. Mechanisms of selenium-induced enhancement of abiotic stress tolerance in plants. In Plant Nutrients and Abiotic Stress Tolerance; Hasanuzzaman, M., Fujita, M., Oku, H., Nahar, K., Hawrylak-Nowak, B., Eds.; Springer: Singapore, 2018; pp. 269-295.

13. Wang, Q.; Ma, X.; Zhang, W.; Pei, H.; Chen, Y. The impact of cerium oxide nanoparticles on tomato (Solanum lycopersicum L.) and its implications for food safety. Metallomics 2012, 4, 1105-1112. [CrossRef] [PubMed] 
14. Rico, C.M.; Lee, S.C.; Rubenecia, R.; Mukherjee, A.; Hong, J.; Peralta-Videa, J.R.; Gardea-Torresdey, J.L. Cerium oxide nanoparticles impact yield and modify nutritional parameters in wheat (Triticum aestivum L.). J. Agric. Food Chem. 2014, 62, 9669-9675. [CrossRef]

15. Andersen, C.P.; King, G.; Plocher, M.; Storm, M.; Pokhrel, L.R.; Johnson, M.G.; Rygiewicz, P.T. Germination and early plant development of ten plant species exposed to titanium dioxide and cerium oxide nanoparticles. Environ. Toxicol. Chem. 2016, 35, 2223-2229. [CrossRef]

16. Mohammadi, M.H.Z.; Panahirad, S.; Navai, A.; Bahrami, M.K.; Kulak, M.; Gohari, G. Cerium oxide nanoparticles (CeO 2 -NPs) improve growth parameters and antioxidant defense system in Moldavian balm (Dracocephalum moldavica L.) under salinity stress. Plant Stress 2021, 1, 100006. [CrossRef]

17. Wang, H.; Kou, X.; Pei, Z.; Xiao, J.Q.; Shan, X.; Xing, B. Physiological effects of magnetite $\left(\mathrm{Fe}_{3} \mathrm{O}_{4}\right)$ nanoparticles on perennial ryegrass (Lolium perenne L.) and pumpkin (Cucurbita mixta) plants. Nanotoxicology 2011, 5, 30-42. [CrossRef] [PubMed]

18. Elfeky, S.A.; Mohammed, M.A.; Khater, M.S.; Osman, Y.A.; Elsherbini, E. Effect of magnetite nano-fertilizer on growth and yield of Ocimum basilicum L. Int. J. Indig. Med. Plants. 2013, 46, 1286-1293.

19. Fahad; Balouch, A.; Agheem, M.H.; Memon, S.A.; Baloch, A.R.; Tunio, A.; Abdullah; Pato, A.H.; Jagirani, M.S.; Panah, P.; et al. Efficient mitigation of cadmium and lead toxicity in coriander plant utilizing magnetite $\left(\mathrm{Fe}_{3} \mathrm{O}_{4}\right)$ nanofertilizer as growth regulator and antimicrobial agent. Int. J. Environ. Anal. Chem. 2020, 1-12. [CrossRef]

20. Elsheery, N.I.; Helaly, M.N.; El-Hoseiny, H.M.; Alam-Eldein, S.M. Zinc oxide and silicone nanoparticles to improve the resistance mechanism and annual productivity of salt-stressed mango trees. Agronomy 2020, 10, 558. [CrossRef]

21. Avestan, S.; Ghasemnezhad, M.; Esfahani, M.; Byrt, C.S. Application of nano-silicon dioxide improves salt stress tolerance in strawberry plants. Agronomy 2019, 9, 246. [CrossRef]

22. Liu, J.; Simms, M.; Song, S.; King, R.S.; Cobb, G.P. Physiological effects of copper oxide nanoparticles and arsenic on the growth and life cycle of rice (Oryza sativa japonica 'Koshihikari'). Environ. Sci. Technol. 2018, 52, 13728-13737. [CrossRef] [PubMed]

23. Chahardoli, A.; Karimi, N.; Ma, X.; Qalekhani, F. Effects of engineered aluminum and nickel oxide nanoparticles on the growth and antioxidant defense systems of Nigella arvensis L. Sci. Rep. 2020, 10, 1-11. [CrossRef] [PubMed]

24. Gohari, G.; Safai, F.; Panahirad, S.; Akbari, A.; Rasouli, F.; Dadpour, M.R.; Fotopoulos, V. Modified multiwall carbon nanotubes display either phytotoxic or growth promoting and stress protecting activity in Ocimum basilicum L. in a concentration-dependent manner. Chemosphere 2020, 249, 126171. [CrossRef] [PubMed]

25. Gohari, G.; Mohammadi, A.; Akbari, A.; Panahirad, S.; Dadpour, M.R.; Fotopoulos, V.; Kimura, S. Titanium dioxide nanoparticles $\left(\mathrm{TiO}_{2} \mathrm{NPs}\right)$ promote growth and ameliorate salinity stress effects on essential oil profile and biochemical attributes of Dracocephalum moldavica. Sci. Rep. 2020, 10, 1-14. [CrossRef] [PubMed]

26. Lei, Z.; Mingyu, S.; Xiao, W.; Chao, L.; Chunxiang, Q.; Liang, C.; Hao, H.; Xiaoqing, L.; Fashui, H. 2008. Antioxidant stress is promoted by nano-anatase in spinach chloroplasts under UV-B radiation. Biol. Trace Elem. Res. 2008, 121, 69-79. [CrossRef]

27. Sheikhalipour, M.; Esmaielpour, B.; Behnamian, M.; Gohari, G.; Giglou, M.T.; Vachova, P.; Rastogi, A.; Brestic, M.; Skalicky, M. Chitosan-selenium nanoparticle (Cs-Se NP) foliar spray alleviates salt stress in bitter melon. Nanomaterials 2021, 11, 684. [CrossRef] [PubMed]

28. Abdel Latef, A.A.H.; Srivastava, A.K.; El-sadek, M.S.A.; Kordrostami, M.; Tran, L.S.P. Titanium dioxide nanoparticles improve growth and enhance tolerance of broad bean plants under saline soil conditions. Land Degrad. Dev. 2018, 29, 1065-1073. [CrossRef]

29. Khan, M.N. Nano-titanium dioxide $\left(\right.$ nano- $\left.-\mathrm{TiO}_{2}\right)$ mitigates $\mathrm{NaCl}$ stress by enhancing antioxidative enzymes and accumulation of compatible solutes in tomato (Lycopersicon esculentum Mill.). J. Plant Sci. 2016, 11, 1-11. [CrossRef]

30. Zeng, J.; Chen, A.; Li, D.; Yi, B.; Wu, W. Effects of salt stress on the growth, physiological responses, and glycoside contents of Stevia rebaudiana Bertoni. J. Agric. Food Chem. 2013, 61, 5720-5726. [CrossRef]

31. Reis, M.; Coelho, L.; Santos, G.; Kienle, U.; Beltrão, J. Yield response of stevia (Stevia rebaudiana Bertoni) to the salinity of irrigation water. Agric. Water Manag. 2015, 152, 217-221. [CrossRef]

32. Cantabella, D.; Piqueras, A.; Acosta-Motos, J.R.; Bernal-Vicente, A.; Hernández, J.A.; Díaz-Vivancos, P. Salt-tolerance mechanisms induced in Stevia rebaudiana Bertoni: Effects on mineral nutrition, antioxidative metabolism and steviol glycoside content. Plant Physiol. Biochem. 2017, 115, 484-496. [CrossRef] [PubMed]

33. Fallah, F.; Nokhasi, F.; Ghaheri, M.; Kahrizi, D.; Agha, A.B.A.; Ghorbani, T.; Kazemi, E.; Ansarypour, Z. Effect of salinity on gene expression, morphological and biochemical characteristics of Stevia rebaudiana Bertoni under in vitro conditions. Cell. Mol. Biol. 2017, 63, 102-106. [CrossRef] [PubMed]

34. Javed, R.; Gürel, E. Salt stress by $\mathrm{NaCl}$ alters the physiology and biochemistry of tissue culture-grown Stevia rebaudiana Bertoni. Turk. J. Agric. For. 2019, 115, 484-496.

35. Kurunc, A.; Aslan, G.E.; Karaca, C.; Tezcan, A.; Turgut, K.; Karhan, M.; Kaplan, B. Effects of salt source and irrigation water salinity on growth, yield and quality parameters of Stevia rebaudiana Bertoni. Sci. Hortic. 2020, 270, 109458. [CrossRef]

36. Shahverdi, M.A.; Omidi, H.; Tabatabaei, S.J. Stevia (Stevia rebaudiana Bertoni) responses to NaCl stress: Growth, photosynthetic pigments, diterpene glycosides and ion content in root and shoot. J. Saudi Soc. Agric. Sci. 2019, 18, 355-360. [CrossRef]

37. Yang, F.; Hong, F.; You, W.; Liu, C.; Gao, F.; Wu, C.; Yang, P. Influence of nano-anatase $\mathrm{TiO}_{2}$ on the nitrogen metabolism of growing spinach. Biol. Trace Elem. Res. 2006, 110, 179-190. [CrossRef]

38. Frazier, T.P.; Burklew, C.E.; Zhang, B. Titanium dioxide nanoparticles affect the growth and microRNA expression of tobacco (Nicotiana tabacum). Funct. Integr. Genom. 2014, 14, 75-83. [CrossRef] [PubMed] 
39. Tumburu, L.; Andersen, C.P.; Rygiewicz, P.T.; Reichman, J.R. Molecular and physiological responses to titanium dioxide and cerium oxide nanoparticles in Arabidopsis. Environ. Toxicol. Chem. 2017, 36, 71-82. [CrossRef] [PubMed]

40. Mingyu, S.; Fashui, H.; Chao, L. Effects of nano-anatase $\mathrm{TiO}_{2}$ on absorption, distribution of light, and photoreduction activities of chloroplast membrane of spinach. Biol. Trace Elem. Res. 2007, 118, 120-130. [CrossRef]

41. Rahneshan, Z.; Nasibi, F.; Moghadam, A.A. Effects of salinity stress on some growth, physiological, biochemical parameters and nutrients in two pistachio (Pistacia vera L.) rootstocks. J. Plant Interact. 2018, 13, 73-82. [CrossRef]

42. Zahedi, S.M.; Abdelrahman, M.; Hosseini, M.S.; Hoveizeh, N.F.; Tran, L.S.P. Alleviation of the effect of salinity on growth and yield of strawberry by foliar spray of selenium-nanoparticles. Environ. Pollut. 2019, 253, 246-258. [CrossRef] [PubMed]

43. Morales-Espinoza, M.C.; Cadenas-Pliego, G.; Pérez-Alvarez, M.; Hernández-Fuentes, A.D.; de la Fuente, M.C.; BenavidesMendoza, A.; Valdés-Reyna, J.; Juárez-Maldonado, A. Se nanoparticles induce changes in the growth, antioxidant responses, and fruit quality of tomato developed under $\mathrm{NaCl}$ Stress. Molecules 2019, 24, 3030. [CrossRef] [PubMed]

44. Munns, R.; Tester, M. Mechanisms of salinity tolerance. Ann. Rev. Plant Biol. 2008, 59, 651-681. [CrossRef]

45. Shamsul, H.; Qaiser, H.; Alyemeni, M.N.; Wani, A.S.; Pichtel, J.; Aqil, A. Role of proline under changing environments: A review. Plant Signal. Behav. 2012, 7, 1456-1466.

46. Ullrich, W.R. Salinity and nitrogen nutrition. In Salinity: Environment-Plants-Molecules; Läuchli, A., Lüttge, U., Eds.; Kluwer Academic Publishers: Dordrecht, The Netherlands, 2002; pp. 229-248.

47. Sotoodehnia-Korani, S.; Iranbakhsh, A.; Ebadi, M.; Majd, A.; Ardebili, Z.O. Selenium nanoparticles induced variations in growth, morphology, anatomy, biochemistry, gene expression, and epigenetic DNA methylation in Capsicum annuum; an in vitro study. Environ. Pollut. 2020, 265, 114727. [CrossRef] [PubMed]

48. Zahedi, S.M.; Hosseini, M.S.; Meybodi, N.D.H.; da Silva, J.A.T. Foliar application of selenium and nano-selenium affects pomegranate (Punica granatum cv. Malase Saveh) fruit yield and quality. S. Afr. J. Bot. 2019, 124, 350-358. [CrossRef]

49. Yuan, S.J.; Chen, J.J.; Lin, Z.Q.; Li, W.W.; Sheng, G.P.; Yu, H.Q. Nitrate formation from atmospheric nitrogen and oxygen photocatalysed by nano-sized titanium dioxide. Nat. Commun. 2013, 4, 1-7. [CrossRef]

50. Tripathy, B.C.; Oelmüller, R. Reactive oxygen species generation and signaling in plants. Plant Signal. Behav. 2012, 7, 1621-1633. [CrossRef]

51. Mittler, R. Oxidative stress, antioxidants and stress tolerance. Trends Plant Sci. 2002, 7, 405-410. [CrossRef]

52. Racchi, M.L. Antioxidant defenses in plants with attention to Prunus and Citrus spp. Antioxidants 2013, 2, 340-369. [CrossRef]

53. Taârit, M.B.; Msaada, K.; Hosni, K.; Marzouk, B. Fatty acids, phenolic changes and antioxidant activity of clary sage (Salvia sclarea L.) rosette leaves grown under saline conditions. Ind. Crops Prod. 2012, 38, 58-63. [CrossRef]

54. Lim, J.H.; Park, K.J.; Kim, B.K.; Jeong, J.W.; Kim, H.J. Effect of salinity stress on phenolic compounds and carotenoids in buckwheat (Fagopyrum esculentum M.) sprout. Food Chem. 2012, 135, 1065-1070. [CrossRef] [PubMed]

55. Wong, C.C.; Li, H.B.; Cheng, K.W.; Chen, F. A systematic survey of antioxidant activity of 30 Chinese medicinal plants using the ferric reducing antioxidant power assay. Food Chem. 2006, 97, 705-711. [CrossRef]

56. Hichem, H.; Mounir, D. Differential responses of two maize (Zea mays L.) varieties to salt stress: Changes on polyphenols composition of foliage and oxidative damages. Ind. Crops Prod. 2009, 30, 144-151. [CrossRef]

57. Hussein, R.A.; El-Anssary, A.A. Plants secondary metabolites: The key drivers of the pharmacological actions of medicinal plants. Herb. Med. 2019, 1, 13.

58. Wang, M.; Lamers, R.J.A.; Korthout, H.A.; van Nesselrooij, J.H.; Witkamp, R.F.; van der Heijden, R.; Voshol, P.J.; Havekes, L.M.; Verpoorte, R.; van der Greef, J. Metabolomics in the context of systems biology: Bridging traditional Chinese medicine and molecular pharmacology. Phytother. Res. 2005, 19, 173-182. [CrossRef] [PubMed]

59. Verpoorte, R. Exploration of nature's chemodiversity: The role of secondary metabolites as leads in drug development. Drug Discov. 1998, 3, 232-238. [CrossRef]

60. Ghaheri, M.; Kahrizi, D.; Bahrami, G.; Mohammadi-Motlagh, H.R. Study of gene expression and steviol glycosides accumulation in Stevia rebaudiana Bertoni under various mannitol concentrations. Mol. Biol. Rep. 2019, 46, 7-16. [CrossRef] [PubMed]

61. Ceunen, S.; Geuns, J.M. Steviol glycosides: Chemical diversity, metabolism, and function. J. Nat. Prod. 2013, 76, 1201-1228, [CrossRef] [PubMed]

62. Ghorbanpour, M. Major essential oil constituents, total phenolics and flavonoids content and antioxidant activity of Salvia officinalis plant in response to nano-titanium dioxide. Indian J. Plant Physiol. 2015, 20, 249-256. [CrossRef]

63. Ahmad, B.; Shabbir, A.; Jaleel, H.; Khan, M.M.A.; Sadiq, Y. Efficacy of titanium dioxide nanoparticles in modulating photosynthesis, peltate glandular trichomes and essential oil production and quality in Mentha piperita L. Curr. Plant Biol. 2018, 13, 6-15. [CrossRef]

64. Li, D.; Zhou, C.; Zhang, J.; An, Q.; Wu, Y.; Li, J.Q.; Pan, C. Nanoselenium foliar applications enhance the nutrient quality of pepper by activating the capsaicinoid synthetic pathway. J. Agric. Food Chem. 2020, 68, 9888-9895. [CrossRef] [PubMed]

65. Rajaee Behbahani, S.; Iranbakhsh, A.; Ebadi, M.; Majd, A.; Ardebili, Z.O. Red elemental selenium nanoparticles mediated substantial variations in growth, tissue differentiation, metabolism, gene transcription, epigenetic cytosine DNA methylation, and callogenesis in bitter melon (Momordica charantia); an in vitro experiment. PLoS ONE 2020, 15, e0235556. [CrossRef] [PubMed]

66. Marslin, G.; Sheeba, C.J.; Franklin, G. Nanoparticles alter secondary metabolism in plants via ROS burst. Front. Plant Sci. 2017, 8, 832. [CrossRef] [PubMed] 
67. Sairam, R.; Srivastava, G. Changes in antioxidant activity in sub-cellular fractions of tolerant and susceptible wheat geno-types in response to long term salt stress. Plant Sci. 2002, 162, 897-904. [CrossRef]

68. Arnon, A. Method of extraction of chlorophyll in the plants. Agron. J. 1967, 23, 112-121.

69. Silva, E.N.; Ferreira-Silva, S.L.; de Vasconcelos Fontenele, A.; Ribeiro, R.V.; Viégas, R.A.; Silveira, J.A.G. Photosynthetic changes and protective mechanisms against oxidative damage subjected to isolated and combined drought and heat stresses in Jatropha curcas plants. J. Plant Physiol. 2010, 167, 1157-1164. [CrossRef]

70. Maxwell, K.; Johnson, G.N. Chlorophyll fluorescence-A practical guide. J. Exp. Bot. 2000, 51, 659-668. [CrossRef] [PubMed]

71. Bates, L.S.; Waldren, R.P.; Teare, I. Rapid determination of free proline for water-stress studies. Plant Soil 1973, 39, $205-207$. [CrossRef]

72. Heath, R.L.; Packer, L. Photoperoxidation in isolated chloroplasts: I. Kinetics and stoichiometry of fatty acid peroxidation. Arch. Biochem. Biophys. 1968, 125, 189-198. [CrossRef]

73. Alexieva, V.; Sergiev, I.; Mapelli, S.; Karanov, E. The effect of drought and ultraviolet radiation on growth and stress marker in pea and wheat. Plant Cell Environ. 2001, 24, 1337-1344. [CrossRef]

74. Nanjo, T.; Kobayashi, M.; Yoshiba, Y.; Kakubari, Y.; Yamaguchi-Shinozaki, K.; Shinozaki, K. Antisense suppression of proline degradation improves tolerance to freezing and salinity in Arabidopsis thaliana. FEBS Lett. 1999, 461, 205-210. [CrossRef]

75. Hemeda, H.M.; Klein, B.P. Effects of naturally occurring antioxidants on peroxidase activity of vegetable extracts. J. Food Sci. 1990, 55, 184-185. [CrossRef]

76. Aebi, H. Catalase. Methods Enzym. Anal. 1983, 59, 309-314.

77. Giannopolitis, C.N.; Ries, S.K. Superoxide dismutases: I. Occurrence in higher plants. Plant Physiol. 1977, 59, 309-314. [CrossRef]

78. Nakano, Y.; Asada, K. Hydrogen peroxide is scavenged by ascorbate-specific peroxidase in spinach chloroplasts. Plant Cell Physiol. 1981, 22, 867-880.

79. Chun, O.K.; Kim, D.O.; Lee, C.Y. Superoxide radical scavenging activity of the major polyphenols in fresh plums. J. Agric. Food Chem. 2003, 51, 8067-8072. [CrossRef]

80. Suja, K.; Jayalekshmy, A.; Arumughan, C. Antioxidant activity of sesame cake extract. Food Chem. 2005, 91, 213-219. [CrossRef]

81. Martins, P.M.; Thorat, B.N.; Lanchote, A.D.; Freitas, L.A. Green extraction of glycosides from Stevia rebaudiana (Bert.) with low solvent consumption: A desirability approach. Resour. Effic. Technol. 2016, 2, 247-253. [CrossRef] 